\title{
STATUS OF HEALTH AND ENVIRONMENTAL RESEARCH RELATIVE TO DIRECT COAL LIQUEFACTION: 1976 TO THE PRESENT
}

June 1982

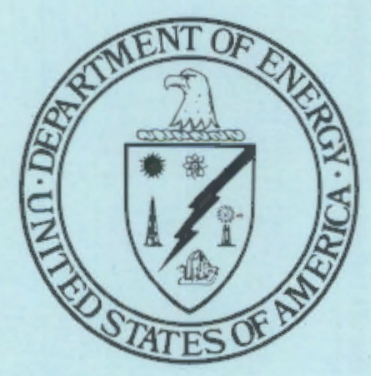

Office of Health and Environmental Research

Office of Energy Research U.S. Department of Energy 


\title{
DISCLAIMER
}

This report was prepared as an account of work sponsored by an agency of the United States Government. Neither the United States Government nor any agency thereof, nor any of their employees, makes any warranty, express or implied, or assumes any legal liability or responsibility for the accuracy, completeness, or usefulness of any information, apparatus, product, or process disclosed, or represents that its use would not infringe privately owned rights. Reference herein to any specific commercial product, process, or service by trade name, trademark, manufacturer, or otherwise, does not necessarily constitute or imply its endorsement, recommeidation, or favoring by the United States Government or any agency thereof. The views and opinions of authors expressed herein do not necessarily state $\mathrm{cr}$ reflect those of the United States Government or any agency thereof.

\author{
PACIFIC NORTHWEST I.ABORATORY \\ operated by \\ BATTELLE \\ for the \\ UNITED STATES DEPARTMENT OF ENERGY \\ under Contract DE-AC06-76RLO 1830
}

\begin{tabular}{|c|c|}
\hline \multicolumn{2}{|c|}{ Printed in the United States of America } \\
\hline \multicolumn{2}{|c|}{ Available from } \\
\hline \multirow{4}{*}{\multicolumn{2}{|c|}{$\begin{array}{c}\text { National Technical Information Service } \\
\text { United States Department of Commerce } \\
5285 \text { Port Reval Road } \\
\text { Springfield, Virginia } 22151\end{array}$}} \\
\hline & \\
\hline & \\
\hline & \\
\hline \multirow{2}{*}{\multicolumn{2}{|c|}{$\begin{array}{l}\text { NTIS Price Codes } \\
\text { Microfiche } \mathrm{A01}\end{array}$}} \\
\hline & \\
\hline \multicolumn{2}{|c|}{ Printed Copy } \\
\hline & Price \\
\hline Pages & Codes \\
\hline $001-025$ & $\mathrm{~A} 02$ \\
\hline $026-050$ & $\mathrm{~A} 03$ \\
\hline $051-075$ & $\mathrm{AO4}$ \\
\hline 076-100 & A05 \\
\hline $10 \div-125$ & $\mathrm{~A} 06$ \\
\hline $126-150$ & $\mathrm{~A} 07$ \\
\hline $151-175$ & $\mathrm{~A} 08$ \\
\hline $176-200$ & A09 \\
\hline $207-225$ & $\mathrm{~A} 010$ \\
\hline $226-250$ & A011 \\
\hline $251-275$ & A012 \\
\hline $276-300$ & A013 \\
\hline
\end{tabular}




\title{
33679000596363
}

DOE $/$ NBM- 1016

PNL-4176

UC- $11,20 \mathrm{e}, 41,59,90 \mathrm{~d}$

\section{STATUS OF HEALTH AND ENVIRONMENTAL RESEARCH \\ RELATIVE TO DIRECT COAL LIQUEFACTION: \\ 1976 TO THE PRESENT}

\section{Prepared for the U.S. Department of Energy by the Staffs of:}

\author{
The Pacific Northwest Laboratory \\ P. 0. Box 999 \\ Richland, Washington 99352 \\ (under Contract DE-AC06-76RLO-1830)
}

and
The Oak Ridge National Laboratory
P. 0. Box X
Oak Ridge, Tennessee 37830
(under Contract W-7405-eng-26)

June 1982 

STATUS OF HEALTH AND ENVIRONMENTAL RESEARCH

RELATIVE TO DIRECT COAL LIQUEFACTION:

1976 TO THE PRESENT

EDITED BY

R. H. Gray, Manager

Coal Liquefaction Environmental Research Program

Pacific Northwest Laboratory

Richland, Washington 99352

and

K. E. Cowser, Manager

Life Sciences Synthetic Fuels Program

Oak Ridge National Laboratory

Oak Ridge, Tennessee 37830

PRINCIPAL CONTRIBUTORS

R. H. Gray, Coal Liquefaction Environmental Research Program Office

D. D. Mahlum, Biological Sciences Department

P. J. Mellinger, Environmental Sciences Department

J. A. Strand, Environmental Sciences Department

W. C. Weimer, Physical Sciences Department

and other staff of the

Pacific Northwest Laboratory

Richland, Washington 99352

and

J. L. Epler, Biology Division

R. J. Fry, Bilogy Division

C. W. Gehrs, Environmental Sciences Division

J. M. Giddings, Environmental Sciences Division

M. R. Guerin, Analytical Chemistry Division

J. M. Holland, Biology Division

H. Inhaber, Health and Safety Research Division

and other staff of the

Oak Ridge National Laboratory

Oak Ridge, Tennessee 37830 


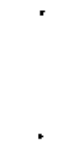


CONTENTS

Page

ACKNOWLEDGMENTS . . . . . . . . . . . . . . . . . . . . . . . vi

ABBREVIATIONS ...................................... vi

EXECUTIVE SUMMARY . . . . . . . . . . . . . . . . . . . . . . . . ix

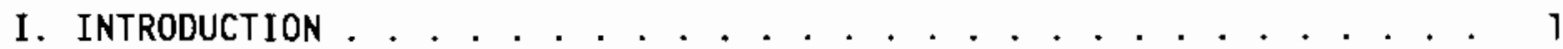

II. MAJOR ISSUES AND CONCERNS ......................... 3

III. RESEARCH STRATEGY . . . . . . . . . . . . . . . . . . . . . . . 7

IV. RESULTS TO DATE . . . . . . . . . . . . . . . . . . . . . . . . 9

V. RISK ASSESSMENT . . . . . . . . . . . . . . . . . . . . . . . . . . 43

VI. RESEARCH AND DEVELOPMENT NEEDS . . . . . . . . . . . . . . . . . 45

VII. BIBLIOGRAPHY OF DIRECT-COAL-LIQUEFACTION-RELATED HEALTH AND ENVIRONMENTAL EFFECTS RESEARCH . . . . . . . . . . . . . . . . . . . . . 53 


\section{ACKNOWLEDGMENTS}

Many individuals were involved in the research and/or made valuable contributions during preparation of this document. We are grateful for their support. We especially wish to thank P. Cho, A. P. Duhame1, G. E. Stapleton, and $F$. J. Wobber, who kindly reviewed drafts of the manuscript and provided critical input to its content. Manuscript preparation was supported by the U.S. Department of Energy's (DOE) Office of Energy Research (OER) under Contract 0E-AC06-76RL0-1830 with Battel le Memorial Institute, Pacific Northwest Laboratory and Contract W-7405-eng-26 with Union Carbide Corporation, 0ak Ridge National Laboratory. Financial support for research efforts described herein was provided by $0 E R$ and the $00 E$ Office of the Assistant Secretary for Foss $i 1$ Energy. 


\section{ABBREVIATIONS}

\begin{tabular}{|c|c|}
\hline $\begin{array}{l}\text { BaP } \\
\text { dg } \\
\text { DOE } \\
\text { DMBA }\end{array}$ & $\begin{array}{l}\text { Benzo[a]pyrene } \\
\text { days gestation } \\
\text { Department of Energy } \\
\text { Dimethylbenzanthracene }\end{array}$ \\
\hline EDS & Exxon Donor Solvent \\
\hline $\mathrm{HD}$ & Heavy distillate \\
\hline $\begin{array}{l}\text { LD } \\
\text { LO }\end{array}$ & $\begin{array}{l}\text { Light distillate } \\
\text { Light oil }\end{array}$ \\
\hline $\begin{array}{l}\text { MD } \\
\text { MFAD }\end{array}$ & $\begin{array}{l}\text { Middle distillate } \\
\text { Mixed-function aminooxidase }\end{array}$ \\
\hline NMHC & Nonmethane hydrocarbons \\
\hline ORNL & Oak Ridge National Laboratory \\
\hline $\begin{array}{l}\text { PAA } \\
\text { PAH } \\
\text { PDU } \\
\text { PMA } \\
\text { PNL } \\
\text { PS }\end{array}$ & $\begin{array}{l}\text { Primary aromatic amine } \\
\text { Polynuclear aromatic hydrocarbon } \\
\text { Process development unit } \\
\text { Phorbol myristate acetate } \\
\text { Pacific Northwest Laboratory } \\
\text { Process solvent }\end{array}$ \\
\hline $\begin{array}{l}\text { SCF } \\
\text { SRC }\end{array}$ & $\begin{array}{l}\text { Standard cubic feet } \\
\text { Solvent refined coal }\end{array}$ \\
\hline UV & U]traviolet \\
\hline $\begin{array}{l}\text { WS } \\
\text { WSF }\end{array}$ & $\begin{array}{l}\text { Wash solvent } \\
\text { Water soluble fraction }\end{array}$ \\
\hline 2-AA & 2-aminoanthracene \\
\hline
\end{tabular}





\section{EXECUTIVE SUMMARY}

This document describes the status of health and environmental research efforts (1976 to the present), supported by the U.S. Department of Energy (DOE), to assist in the development of environmentally acceptable coal liquefaction processes. Four major direct coal liquefaction processes are currently in (or have been investigated at) the pilot plant stage of development. These include two solvent refined coal processes (SRC-I and-II), H-coal (a catalytic liquefaction process) and Exxon donor solvent (EDS).

Several organizations were selected by DOE to study the health, environmental and safety aspects of direct coal liquefaction processes. The Pacific Northwest Laboratory (PNL) was assigned responsibility for evaluating SRC process materials and prepared comprehensive health and environmental effects research program plans for SRC-I and -II. A similar program plan was prepared for $\mathrm{H}$-coal process materials by the Oak Ridge National Laboratory (ORNL). A program has also been developed for EDS process materials by Exxon Research and Engineering Co. These programs were initiated in FY 1976 and 1981, respectively.

Objectives of DOE's environmental research program are to:

- identify and perform research on the long-term health and environ mental issues associated with direct coal liquefaction

- evaluate control technology and ameliorative options to permit the design of environmentally acceptable coal liquefaction processes

- assess and quantify potential risks to man and the environment from large-scale deployment of direct coal liquefaction processes.

The program includes short-term screening of coal-derived materials for potential health and ecological effects. Longer-term assays are used to eval 
uate materials considered most representative of potential commercial practice and with greatest potential for human exposure or release to the environment. Effects of process modification, control technologies and changing operational conditions on potential health and ecological effects are also being evaluated. Health and environmental risk assessments for $\mathrm{H}$-coal and SRC-II processes were initiated in FY 1981. These asssessments are being conducted to assist in formulating cost-effective environmental research programs and to estimate health and environmental risks associated with a large-scale coal liquefaction industry.

Results to Date

Significant results of DOE's health and environmental research efforts; relative to coal liquefaction include the following:

\section{(1) Chemical Characterization. Coal-derived materials are extremely} complex chemically, and analysis requires sophisticated methods and techniques. Coal liquids are enriched in polynuclear aromatic hydrocarbon (PAH), basic, acidic and insoluble constituents compared to crude petroleums. Higher-boilingrange materials are enriched in both basic nitrogen-containing and highly polar materials that are believed to be responsible for the biological activity observed in coal liquids.

(2) Health Effects. Higher-boiling-range SRC-I process solvent (PS), SRC-II heavy distillate (HD) and process development unit (PDU)-derived $\mathrm{H}$-coal distillates are mutagenic in microbial test systems; lower-boiling-range SRC-I light oil (LO) and wash solvent (WS), SRC-II light distillate (LD) and middle distillate (MD) and PDU-derived H-coal materials are not. Studies with distil- 
lation cuts showed that the mutagenically active constituents of SRC-II HD occurred in those liquids boiling above $371^{\circ} \mathrm{C}\left(700^{\circ} \mathrm{F}\right)$. The latter make up about $20 \%$ of the full-boiling-range material. Chemical fractionation and characterization, coupled with microbial assays, suggested that the highest specific mutagenic activity was associated with polycyclic primary aromatic amines (PAA). However, genetically active fractions were also enriched in azaarenes and polarsubstituted aromatics which may also affect genetic activity. 0ther in vitro studies indicated that materials showing mutagenic activity in microbial assays also cause transformation in cultured mammalian cells.

An SRC-II liquid was negative in several mammalian mutagenes is assays (male-dominant lethality, specific locus and mouse spot tests). A PDU-derived coal liquid (Synthoil) was positive in these tests. Both materials were cytotoxic.

Carcinogenesis studies showed that SRC-II HD, high-boiling-range POUderived H-coal distillates and EDS liquids, shale oil and benzo[a]pyrene produced high incidences of skin tumors. Lower-boiling-range coal liquids do not appear to possess tumorigenic activity.

SRC-II LD, MD and HD, SRC-I LO and PS, and some POU-derived H-coal distillates were moderately toxic after oral administration to rats. SRC-I WS was the most toxic coal liquid tested, probably reflecting its high phenolic content. No coal liquid tested produced skin sensitization when applied intradermally. Eye irritation was noted with some materials, but it was a reversible effect.

Effects of SRC-II LD, MD and HD, and SRC-I LO, WS and PS on fetal development were determined after oral administration of these materials to pregnant rats at 7 to 11 and 12 to 16 days gestation (dg). Pregnant rats were also exposed to SRC-II HD aerosols at 12 to $16 \mathrm{dg}$. Fetal growth and survival 
were decreased by all materials administered at either gestation period. Doses producing fetal effects often produced indications of maternal toxicity. Administration of SRC-I PS and SRC-II HD at 12 to $16 \mathrm{dg}$ increased the incidence of fetal malformations--primarily cleft palate, hypoplastic (immature) lungs and herniated diaphragms. Coal-derived materials were also teratogenic in amphibian and insect test systems.

(3) Ecological Fate and Effects. Aniline and pyridine are nitrogenous compounds that make up about $10 \%$ of coal liquid water-soluble fractions (WSFs). Aniline sorption studies to determine long-term fate of coal liquids in the: environment suggest that migration of organic nitrogen bases, as might occur following a spill, will be retarded in certain eastern soils (e.g., Westmorland silt loam), whereas phenols are relatively mobile. Thus, phenols may be the first compounds to affect ground waters, while anilines may enter food chains through plants and be transferred to higher trophic levels.

Because phenolic compounds may eradicate microbial communities that result in degradation of heavier hydrocarbons, coal liquids may remain in soils longer than petroleum or shale oils. Lysimeter studies with barley confirm this conclusion. Although germination occurred during the second growing season following contaminaton of soils with SRC-II liquid, grain production was significantly reduced.

Bio-uptake studies with plants showed that aniline was more persistent. than phenol. Although the plant absorption rate for aniline was significantly lower than that for phenol, aniline tended to bind to cell-wall materials. Also, less aniline was metabolized to higher-molecular weight compounds. In related studies of $\mathrm{PAH}$ uptake and assimilation by plants, anthracene was taken up from either roots or foliage, translocated and catabolized to compounds of 
lower molecular weights. Thus, certain components (e.g., aniline and anthracene) of coal liquids may accumulate in vegetation.

Gases containing sulfur were identified as common stack emissions during liquefaction and occurred as both reduced ( $\operatorname{COS}, \mathrm{H}_{2} \mathrm{~S}$, carbonyl disulfide $\left[\mathrm{CS}_{2}\right]$, methyl mercaptan $\left[\mathrm{CH}_{3} \mathrm{SH}\right]$ ) and oxidized (sulfur dioxide $\left[\mathrm{SO}_{2}\right]$ ) forms. Reactivity of gases and relative toxicity to plants in descending order were: $\mathrm{SO}_{2} \geqq$ $\mathrm{H}_{2} \mathrm{~S}>\mathrm{COS}>\mathrm{CH}_{3} \mathrm{SH} \geqq \mathrm{CS}_{2}$.

Uptake of sulfur dioxide and ozone by plants was significantly increased at higher relative humidities suggesting that impacts of emissions from coal liquefaction will vary regionally. Other atmospheric pollutants will also affect plant response. Although oxides of nitrogen alone had little effect on vegetation, nitrogen oxides, ozone and sulfur gases together inhibited growth.

Lysimeter studies with barley exposed to SRC-II liquid indicated significant toxicity. However, toxic effects (chlorosis or necrosis) were greatiy reduced following overwintering. Similar studies showed that SRC-I solid product was nontoxic, although layering the SRC-I solid product under a soil overburden retarded root growth.

An increased frequency of morphologic abnormalities was observed in developing cricket embryos exposed to azaarenes, a constituent of coal liquids. Coal liquids were also teratogens, and teratogenic activity appeared to reside in the ether-soluble base fraction which consisted of aromatic amines.

The WSFs of five synthetic oils contained similar contaminants which varied widely in relative concentrations. Major water-soluble components were phenols and cresols with lower levels of xylenols and C3- and C4-substituted phenols. Major neutral components were toluene, xylene and naphthalene. Basic constituents included aniline and $\mathrm{Cl}$ - to $\mathrm{C3}-$ substituted anilines. However, larger multi-ring compounds (naphthol, alkylnaphthalenes, anilines and 
pyridines) were not found. Both anilines and pyridines contributed significantly to WSFs of SRC-II coal liquid.

Rates of dissolution followed theoretical predictions; phenol dissolved most rapidly, while the less water-saluble components dissolved more slowly. Dissolution rates were found to be highly dependent on oil viscosity; phenol dissolved rapidly ( $50 \%$ dissolution in $6 \mathrm{~min}$ ) from a refined distillate, but dissolved more slowly ( $50 \%$ dissolution in $2 \mathrm{hr}$ ) from a heavy syncrude. In other studies, photo-oxidant formation of four coal liquids was nearly identical but was about one-fourth that of a petroleum diesel fuel.

Studies of PAHs showed that volatilization decreased rapidly as molecular size increased. Photolysis increased for larger potentially carcinogenic PAHs. Microbial transformation rates were relatively slow for larger PAHs, suggesting that PAH levels in contaminated aquatic sediments may remain high for several vears after a spill. Sorption of PAHs to particulates was rapidly reversible, and resuspension of sediments during high-water periods may result in release of sediment-bound PAHs into overlying waters.

Acute toxicity studies with a variety of aquatic test species (phytoplankton, invertebrates, fish) showed that coal liquids (SRC-I, -II, or H-coal [raw distillate or fuel oil blend]) were 10 to 1000 times more toxic than comparable petroleum products. Acute toxicity appeared to result from high concentrations of low molecular weight, easily degradable phenolic compounds. Chronic toxicity appeared to be due to higher molecular weight and more persistent compounds which also may include phenols.

Pond microcosm studies with representative coal liquids resulted in extensive changes in community structure and function. Many zooplankton species were eliminated and diatoms were replaced by blue-green algae. Patterns of ecosystem metabolism were also affected. That is, a food web based on plant 
production was replaced by one based on detritus. However, termination of toxic input resulted in partial recovery. Recovery was also observed in simpler test systems for algae exposed to concentrations of a coal liquid causing chronic effects once the toxicant was removed.

\section{Amelioration}

Hydrotreating has been found to reduce the mutagenicity, carcinogenicity and toxicity of coal liquids. For example, hydrotreating reduced the mutagenicity of the SRC-II 2.9:1 MD:HD blend by more than 100-fold. Hydrotreating has also been found to reduce concentrations of two genetically active chemical classes, the PAHs and PAAs. Concentrations of benzo[a]pyrene, a known mutagen/carcinogen, were reduced at least $75 \%$ by hydrotreatment. The PAAs detected in the distillate blend were below the limits of detection in hydrotreated materials and were thus reduced by at least 350-fold. Minimal hydrotreatment reduced the carcinogenicity of POU-derived $\mathrm{H}$-coal materials. Removal of nitrogen compounds by hydrotreating may also reduce teratogenic activity. Finally, hydrotreating reduced the concentration of phenols and, therefore, toxicity to aquatic organisms. Since the chemical agents responsible for mutagenic activity in coal liquids reside predominantly in materials boiling above $371^{\circ} \mathrm{C}\left(700^{\circ} \mathrm{F}\right)$, fractional distillation of the full-boiling-range material might be used to yield a commercial product with reduced toxicity.

\section{Risk Assessment}

Risk assessment is an integral part of DOE's research effort. Assessment includes jdentifying source terms, calculating the magnitude of anticipated emissions and estimating potential health and environmental risks assocjated with a large-scale coal liquefaction industry. Preliminary assessments have been performed and results are being published under separate cover. 



\section{STATUS OF HEALTH AND ENVIRONMENTAL RESEARCH RELATIVE TO DIRECT COAL LIQUEFACTION: 1976 TO THE PRESENT}

\section{INTRODUCTION}

Increasing energy demands, coupled with rising prices and an unstable world oil market, have stimulated international interest in developing alternative sources of fuel. Four direct coal liquefaction processes were being developed by industry in cooperation with the U.S. Department of Energy (DOE). Some of these processes may be ready for large-scale deployment by the 1990s. These include two Solvent Refined Coal processes (SRC-I and -II), H-coal, and Exxon donor solvent (EDS). These processes all produce liquid fuel products. The SRC-I process also produces a low-sulfur, low-ash, solid fuel.

Both SRC process options have been studied at a 50-ton/day pilot plant in Fort Lewis, Washington. The SRC-I process is also being evaluated at a 6-ton/ day pilot plant in Wilsonville, Alabama. The H-coal process is currently being studied at a 200- to 600-ton/day plant in Catlettsburg, Kentucky, and a 250-ton/day EDS pilat plant is operational in Baytown, Texas. A distillate blend from the SRC-II process is considered representative of a commercial boiler fuel, while a full-boiling-range material from the $\mathrm{H}$-coal process is considered representative of a syncrude.

Several organizations were selected by DOE to study the health, environmental and safety aspects of direct coal liquefaction processes. The Pacific Northwest Laboratory (PNL) was assigned responsibility for evaluating SRC processes and prepared and initiated comprehensive health and environmental effects research program plans for SRC-I and -II. Similar program plans were prepared and initiated for the $\mathrm{H}-\mathrm{coal}$ and EDS processes by the Oak Ridge Na- 
tional Laboratory (ORNL) and Exxon Research and Engineering Co., respectively. The programs have the following objectives:

- identify and perform research on the long-term health and environmental issues associated with direct coal liquefaction

- evaluate control technology and ameliorative options to permit the design of environmentally acceptable coal liquefaction processes

- assess and quantify potential risks to man and the environment from large-scale deployment of direct coal liquefaction processes.

This document identifies the health and environmental issues and concerns, describes a research strategy and summarizes results obtained to date from DOE's environmental, health and safety research programs relative to direct coal liquefaction. Research results are discussed and used to define future research efforts. The information summarized in this report is contained in numerous documents, including technical reports, symposium proceedings and open literature publications (see Section VII). 
II. MAJOR ISSUES AND CONCERNS

Table 1 shows major issues being addressed in the health, environmental and safety research programs for direct coal 1 iquefaction. 
TABLE 1. Health and Environmental Research Issues Relative to Direct Liquefaction

Issue

Research

1. Health Effects

A. Toxicology

1) Chemical characterization and monitoring. obtain, store, and characterize, relative to known agents of biomedical concern (e.g., polynuclear aromatics, $\mathrm{N-}$ and $\mathrm{S}$-containing heterocyclics, phenols, and toxic metals) coal liquefaction products, process streams, solid and liquid wastes, and atmospheric emissions. Determine, in coordination with biological assays, the chemical compounds/ compound classes responsible for toxicological effects.

2) Short-term bioassay.

Apply submammalian, microbial and mammalian acute toxicity and teratogenicity tests to coal liquefaction materials to determine potential genotoxicity and acute hazards of exposure. Quantify doseresponse relationships and evaluate relative to other synfuel materials and petroleum products.

3) Chronic bioassay.

Evaluate, in appropriate mammalian systems, carcinogenicity, effects on juvenile development, reproduction, neurotoxicity, and other chronic effects on tissues as a function of route of exposure (inhalation, ingestion, or dermal application). Quantify dose-response relationships and evaluate relative to other synfuel materials and petroleum products. Define, where relevant, the potential for synergistic action of synfuel-related pollutants with selected chemical, biological ard environmental stresses.

B. Occupational Health

1) Industrial hygiene.

Design and implement industrial hygiene programs which will include identification of high-risk workers; educate workers to workplace risks and consequences; develop protective clothing, equipment and decontamination procedures; and maintain medical surveillance of workers. Use toxicologic data to determine sources of potential hazards.

2) Workplace and personnel monitoring. Develop measuring and monitoring systems for 
TABLE 1. (continued)

work areas and personnel that will define potential and actual exposure to hazardous materials.

3) Epidemiology.

Conduct epidemiologic studies on work forces at coal liquefaction facilities. Integrate with information relevant to exposure doses, medical histories, and surveillance.

C. Public Health

Determine the potential for exposure of the general populace to synfuel products, by-products, and wastes as the result of accidental and planned releases. Using relevant toxicological and industrial hygiene data, determine the relative health risk and develop appropriate surveillance equipment and emergency response plans. Where appropriate, implement epidemiologic studies on selected populations.

2. Ecological Fate and Effects
A. Accidental Product Release

B. Solid Waste Leachates

C. Unplanned Solid/Liquid Release

D. Planned Treated Effluent Release

E. Planned/Fugitive Atmospheric Emission

For A through $E$ above

1) Acute and chronic bioassay.

Test coal liquefaction materials for acute and chronic effects on aquatic and terrestrial organisms in ecosystems. Identify chemical compounds/ compound classes responsible for observed effects.

2) Biological and chemical fate. Determine rates of transport and transformation of coal liquefaction materials mediated by chemical and biological processes. Determine potential toxicity of transformation products identified in I.A. Measure bioaccumulation and determine potential for food chain transfer.

3) Field monitoring. Accumulate baseline, operational, and postopera- 
TABLE 1. (continued)

Issue

Research

tional data relevant to ecological fate and effects at coal liquefaction facilities.

3. Risk Assessment

A. Health

Use data from unit operations analyses and potential plant/transportation accident scenarios to identify sources of occupational and environmental exposure, and couple with analyses of dose-effect from toxicological and appropriate epidemiologic studies to identify and quantitate potential occupational and environmental health risks.

B. Ecology

Use data from unjt operations and potential plant/ transportation accident scenarios to identify sources of aquatic and terrestrial ecological exposure and couple with laboratory and field studies to identify and predict ecological risks and potential food chain paths to man.

C. Amelioration (i.e., hydrotreatment, fractional distillation)

Evaluate effectiveness of existing and planned ameliorative measures relative to present and anticipated regulations. Assess impact on occupation and environmental health and on potentially affected ecosystems.

4. End-Use

A. Use of coal liquefaction materials will affect the environment contingent on specific use of materials (e.g., combustion, use as refinery and petrochemical feedstock, etc.). Research required is identified in the preceding components of this table. 


\section{RESEARCH STRATEGY}

Although the goal of DOE's research program is to evaluate the long-term health and environmental effects of a large-scale coal liquefaction industry, there are currently no large-scale (i.e., demonstration/commercial) coal liquefaction facilities in existence. Therefore, the research efforts utilize materials produced at process development units (PDUs) and pilot-scale facilities that are operating or have operated under conditions that approximate potential demonstration/commercial facility practice. In this effort, health, environmental and safety research accompanies engineering development so that results may influence process design at an early stage of development. For comparative purposes, other fossil-derived materials and selected chemicals are also evaluated. These materials, which include shale oil, crude and refined petroleums, and pure forms of known chemical mutagens and carcinogens, assist in placing results obtained with direct coal liquefaction materials in clearer perspective.

Coal liquefaction materials are being subjected to a battery of shortand long-term assays for potential health and environmental effects. Chemica] fractionation and analyses are also performed to identify compounds and compound classes that are biologically active. Acute and other short-term studies provide a first indication of potential health and environmental problems associated with coal liquefaction materials, thereby:

aiding design of additional studies, which involve longer-term, more extensive bioassays and chemical analyses of environmental fate;

providing initial data on materials that have a high potential for human exposure and that may require ameliorative action during process development; 
- providing a semiquantitative analysis for assessing health and environmental risk anticipated from large-scale deployment of coal liquefaction processes.

Longer-term research evaluates materials that are considered most representative of potential demonstration or commercial practice. These materials are subjected to whole-animal and ecosystems studies relative to effects and environmental fate. Results from these studies provide:

- correlation analyses between short-term in vitro and selected in vivo assays and longer-term in vivo assays and ecological studies:

- a basis for development of control technologies and management pro cedures that may reduce environmental risk;

- a quantitative assessment of potential health and environmental risk.

Studies are also being conducted to evaluate the influence of process or operational modifications and control technology options on potential health and environmental effects of coal liquefaction materials. Results from these studies provide:

- a basis for determining effectiveness of control technology options and process modifications to decrease potential health and environmental effects;

- an analysis of health and environmental risks associated with altered plant operations. 


\section{RESULTS TO DATE}

This section is organized in three parts. Part (1) summarizes data on the chemical characterization of coal liquefaction materials. Part (2) summarizes potential health effects data, reviews ongoing and planned occupational health and industrial hygiene efforts, and describes effects of potential ameliorative actions on chemical composition and biological activity of coal liquids. Part (3) summarizes the ecological fate and effects data relative to release of coal-derived materials to the environment.

\section{Part (1): Chemical Characterization}

This section summarizes the chemical information available for materials from coal liquefaction processes that have progressed to the pilot-plant stage (i.e., SRC-I, SRC-II, H-coal, and EDS). In general, the data base varies with the length of time the PDUs and pilot plants have been operational. Limited chemical data are available for materials from some smaller-scale units.

The SRC-II, H-coal, and EDS processes each produce several coal liquids as process streams or as potential products. The SRC-I process produces solid products in addition to a suite of liquid products. Not all of the coalderived materials from each process have undergone the same degree of biological testing or chemical characterization. A thorough evaluation of most of the materials that may be components of products from the SRC-II process has been performed. A more limited set of SRC-I materials has been evaluated. Fewer data are available for representative materials from the $\mathrm{H}$-coal and EDS processes. However, many PDU-derived, $\mathrm{H}$-coal materials have been chemically characterized. 
Two characteristics of coal liquids dictate the manner in which chemical characterization research is performed. First, coal liquids are extremely complex chemically compared to similar boiling-range crude petroleums. Much of this complexity is likely due to chemical reactions that occur during coal dissolution, which fragments the coal structure and produces an extensive variety of smaller molecules. Sophisticated instrumentation and, in some cases, considerable effort are needed to determine even gross chemical characteristics of coal liquids. Second, certain constituents of coal-derived materials responsible for biological activity are present in only ultratrace concentrations and are masked during analysis by major constituents. Thus, the biologically nonactive components (generally the major components in coal liquids) must be separated from the trace quantities of biologically active agents. Separation requires special fractionation methods and state-of-the-art ana* lytical techniques.

General chemical properties of coal liquids have been evaluated at ORNL, PNL, and Exxon Research and Engineering Co. ORNL has developed a broad data base for comparing products from different liquefaction processes, shale oils, and crude petroleum materials. PNL has extensive data on materials from the SRC-I and -II processes. Exxon Research and Engineering Company has data for the EDS process.

Data on chemical class distribution for various coal 1 iquids have beer compared to data for four petroleum crudes and two shale oils. The chemical classes compared were volatiles, insolubles, acids, bases, polynuclear aromatic hydrocarbons (PAH) and other neutral components, Depending on boilingpoint-range (which is directly related to molecular weight), coal liquids may contain a significant amount of material that is insoluble in commonly used organic solvents such as iso-octane. Petroleum crudes contain essentially none 
of this insoluble material. Although the chemical nature of this material has not been elucidated completely, the insolubles probably contain high-molecularweight, polycyclic aromatic materials and very polar, polyfunctional polycyclic aromatic materials. The acid fraction is considerably larger in coal liquids than in either crude petroleums or shale oils and contains phenols and carboxylic acids. The basic fraction is also considerably larger in coal liquids than in other fuels and is composed predominantiy of nitrogen-containing molecules such as pyridines, amines and higher molecular weight azaarenes. The PAH fraction constitutes a greater portion of the coal liquids than it does in shale oil or crude petroleums. The PAH fraction contains two- to seven-ring hydrocarbons, some heteracyclic compounds, and a large number of highly alkyl substituted polycyclic aromatics. The neutral fraction tends to be highest in crude petroleum, but does comprise a significant fraction of some lighter-boiling-range materials from coal liquefaction processes. The neutral fraction contains aliphatic, alicyclic, olefinic, and alkylated monoaromatic materials.

A complex variety of organic and inorganic gases and particulate matter with adsorbed PAH compounds may be released to the atmosphere from coal liquefaction facilities. Identification of the principal compounds released and determination of their potential maximum ground-level concentrations are critical to evaluating impacts on terrestrial systems. Compounds of initial concern have included: $\mathrm{SO}_{2}, \mathrm{H}_{2} \mathrm{~S}, \mathrm{COS}, \mathrm{CS}_{2}, \mathrm{CH}_{3} \mathrm{SH}$, thiophene, benzene, methane, ethane, phenols and PAHs.

In summary, synthetic coal liquids from all processes evaluated so far are enriched in $\mathrm{PAH}$, basic, acidic, and insoluble fractions compared to crude petroleum products. Additionally, the degree of alkylation and substitution on aromatic rings is greater in coal liquids than in natural petroleums. En- 
richment of the above four fractions in coal liquids appears to be a function of boiling range represented by each material. The higher-boiling-point cuts appear to be enriched in PAH and nitrogen- and oxygen-containing molecules in SRC-I and -II and H-coal materials. Data for a full-boiling-range EDS material show the same enrichment in heterocyclic and PAH compounds.

\section{Isolation of Biologically Active Constituents}

Several different approaches to isolate biologically active fractions have been developed. Although details of each approach differ, the rationale is basically the same. The complex coal liquid is fractionated by some relatively standard chemical method. Each fraction is screened biologically, generally with a variety of assays. Fractions containing biologically active agents are further fractionated or chemically treated to make them more amenable to further analyses. Subfractions may be subjected to additional bioassay, and those still showing activity may be subjected to even further chemical identification procedures. This approach has allowed researchers to concentrate on identifying those chemical components that are biologically active and has been applied successfully to SRC-I and -II and H-coal materials.

\section{Part (2): Health Effects}

Health effects research relative to direct coa? liquefaction has emphasized evaluation of process streams and materials that might eventually be used as commercial products. The research effort has also focused on those materials that might cause health effects in workers who would be subject to greater exposures than would the general population. Moreover, once a data base is established to evaluate the potential risk to workers, these data may 
be extrapolated to the general population. Materials that may enter the environment (i.e., from product spills or effluent release) and, therefore, be of concern to the general population are considered in Part (3). The data summarized below were derived mainly from studies on SRC-I and -II and H-coal materia1s. Data from other processes are limited but are presented where appropriate.

\section{Cellular Screening Studies}

A number of in vitro assays have been used to examine various coal-derived materials. These have ranged from microbial assays for mutagenesis to mamnalian cell transformation. The short-term nature of these assays has permitted the accumulation of a considerable data base as shown below.

\section{SRC-I and SRC-II Materials}

There has been considerable research on SRC-I and -II materials which, at the time of their collection, were considered representative of proposed largescale coal liquefaction facilities. SRC-I light oil (LO, bp $<380^{\circ} \mathrm{F}$ ), wash solvent (WS, bp $380-480^{\circ} \mathrm{F}$ ) and process solvent (PS, bp $480-850^{\circ} \mathrm{F}$ ), and SRC-II light ( $L D$, bp $<350^{\circ} \mathrm{F}$ ), middle ( $M D$, bp $350-550^{\circ} \mathrm{F}$ ) and heavy ( $\mathrm{HD}$, bp $550-850^{\circ} \mathrm{F}$ ) distillates were assayed with the Ames (Salmonella) histidine reversion plate assay. No mutagenic activity was observed with the LO, WS, LD or MD. In contrast, substantial activity was found in SRC-I PS and SRC-II HD. The latter showed 20 to 80 times the activity of crude shale oil. The known chemical carcinogen benzo[a]pyrene ( $8 \mathrm{aP})$ used as a positive control showed about nine times the activity of PS and three times the activity of $\mathrm{HD}$. Another we11-known chemical carcinogen, 2-aminoanthracene (2-AA), was about $40 \mathrm{D}$ times as active as PS and about 100 times as active as $H D$ in the Salmonella assay. 
Fractionation by solvent extraction of PS and HD showed that substantial amounts of the mutagenic activity resided in the basic, basic tar, and neutral tar fractions. The basic fraction had the highest specific activity while the tar fractions had the highest total activity. The neutral, acid, and PAH fractions showed no activity. When crude PS or HD or the basic, basic tar, or neutral tar fractions were further fractionated using thin Jayer chromatography (TLC), the mutagenic activity was confined to a region containing relatively polar compounds. Chemical analyses of the TLC regions high in mutagenic activity indicated high levels of nitrogen-containing materials including polycyclic primary aromatic amines (PAAs), azaarenes, and carbazoles. Because the data suggested that PAAs may be responsible for much of the genotoxicity ooserved in coal-derived materials, additional fractionation methods, including LH-20 Sephadex and high pressure liquid chromatography (HPLC) were applied. Data from these fractionation methods further support the view that PAAs are the major chemical classes responsible for genotoxicity in PS and HD.

Additional studies were conducted to confirm whether PAAs were the predominant genotoxic factors in coal-derived materials. One study utilized nitrous acid, which selectively converts polycyclic primary amines to their corresponding phenols to eliminate the primary amine group. Nitrous acid treatment removes genotoxic activity of standard PAA compounds such as 2-AA, aminopyrene, aminochrysene, etc., but does not affect the genotoxicity of pure PAHs such as BaP or nitrogen heterocycles such as benzacridine. Thus, nitrous acid provided a relatively specific means of removing genotoxic activity caused by PAAs.

When SRC-I PS and SRC-II HD were subjected to nitrous acid treatment and assayed, at least $90 \%$ of the mutagenic activity was removed. Similar data were obtained when highly active fractions prepared from these crude coal liquids were treated in a similar manner. 
Another study to define the role of PAAs in determining mutagenicity of coal-derived materials utilized an enzymatic activation system that is highly specific for PAAs. Mixed-function amineoxidase (MFAO) was isolated from pig liver and shown to specifically activate PAAs to a mutagenic form. The MFAO activated crude coal liquids and their fractions that contained PAAs. Studies comparing MFAO to standard S-9 activation gave similar results, indicating that the activity observed after 5-9 activation was due mainly to the presence of PAAs. Thus, two independent approaches, one which decreased mutagenic activity (i.e., nitrous acid treatment) and the other which increased mutagenic activity (i.e., MFAO treatment), indicated that the PAAs were the major genotoxic factors in coal liquids and their fractions.

Analyses of SRC-I PS, SRC-II HD and an SRC-II distillate blend have identified about 70 PAAs. These amines range in size from two to six aromatic rings and include numerous alkyl-substituted compounds. Relative mutagenicity of different chemical subfractions generally correlates with concentrations of PAAs having three or more aromatic rings. Mutagenicity does not appear to correlate with any other chemical constituents.

Some SRC materials and their fractions have been evaluated in the second tier mammalian cell transformation assay. This assay also showed that while high-boiling-range materials, SRC-I PS and SRC-II HO, were active in transforming Syrian hamster embryo (SHE) cells, lower-boiling-range materials, SRC-I LO and WS, and SRC-II LD and MD, were inactive. SRC-II HO was as active as BaP and several times more active than 2-AA (both known mutagens/carcinogens) in this assay. When solvent-extracted fractions of these materials were tested, the PAH fraction was the most active, followed by the basic, basic tar, and neutral tar fractions. Cells transformed by SRC-I PS and subsequentiy undergoing several passages in culture produced tumors when injected into nude mice. 
Boiling-point cuts prepared from a distillate blend (MD:HD) were also evaluated in the SHE transformation assay. Low biological activity was obtained with fractions boiling between 640 and $880^{\circ} \mathrm{F}$. Above $880^{\circ} \mathrm{F}$, transformation activity increased markedly. These results differ somewhat from those obtained in the Ames assay where measurable activity was only seen above $700^{\circ} \mathrm{F}$.

\section{$\underline{\mathrm{H}-\mathrm{Coal}}$ and EDS Materials}

Studies with PDU-derived H-coal materials showed that distillates designated as atmospheric still overheads (bp 150-650 $\mathrm{F}$ ), and obtained during operation in either the fuel oil or syncrude mode, were not mutagenic in the Ames system. The higher boiling crudes, atmospheric still bottoms, vacuum still overheads, and vacuum still bottoms, from both modes of operation were mutagenic. Fractionation studies indicate that most of the mutagenic activity of these materials resides in the ether-soluble base and the neutral polyaromatic fractions. Some additional activity was found in the insoluble base (tar) and in the neutral polar fractions. However, for the insoluble base fraction, mutagenic activity was significant for only high-boiling point, high-molecularweight materials with large concentrations of tars. The mutagenically active neutral polyaromatic fractions of some coal liquids are enriched in azaarenes and substituted azaarenes, implicating these compounds in microbial activity. Additionally, a series of polycyclic aromatic amines has been identified in a coal oil and several gasifier tars. However, the relationship of these PAAs to biological activity has not been directly defined. One additional fraction that appears to have some biological activity is the neutral polar fraction from a sample of $\mathrm{H}$-coal material. This fraction contained numerous hydroxylated and carbonyl compounds and a series of nitrogen-containing compounds. The nitrogen compounds included azaarenes and polycyclic PAAs. However, the- 
cause of the extremely complex chemical nature of this neutral fraction, the exact cause of biological activity is unkown.

Studies to characterize biologically active agents in $\mathrm{H}$-coal materials have thus far been limited to PDU materials. However, it is probable that the biologically active agents in $\mathrm{H}-\mathrm{coal}$ materials are similar to those in SRC-I and -II materials. Detection of activity in neutral fractions of $\mathrm{H}$-coal materials, compared to lack of activity in similar fractions of SRC materials, may reflect differences in fractionation procedures.

The naphtha, solvent, heavy gas oil, vacuum gas oil, and residue from the EDS process have also been assayed for mutagenic activity in the Ames system. A11 but the naphtha were positive. The components responsible for the activity in EDS materials have not been investigated to the same extent as those from SRC and $\mathrm{H}$-coal.

\section{Structure/Activity Relationships}

The discovery that PAAs, azaarenes and polar substituted aromatics are important microbial mutagens in coal liquids has generated interest in determining the relative biological activities of different structural isomers to ascertain mechanisms of action. Mutagenic activities of a series of primary, secondary, and tertiary polycylic aromatic amines and several azaarenes have been compared. Studies were designed to evaluate the effect of nitrogen atom position within an aromatic ring, the effect of amino or nitro substitution location on an aromatic ring, and the effect of amino substitution location on $\mathrm{N}$-heterocyclic aromatic compounds. The effect of alkyl versus aryl substitution to the amino group of a series of polycyclic aromatic amines was also evaluated. Presence or absence of nitrogen in a fused-ring system did not appear to be as important as the number of rings (up to five, the maximum number 
studied) in causing mutagenic activity. Additionally, compounds with amino and nitro substituents on fused-ring systems produced high mutagenic potential compared to compounds with nitrogen incorporated in the fused-ring as a secondary (indolic) or tertiary (aza) amine. Finally, for each of four series of amines (a one-, a two-, a three- and a four-membered ring system), activity of the primary-, secondary-, and tertiary-substituted amines was about equal. Additional studies are planned to better define the relationship between chemical structure and biological activity.

\section{$\underline{\text { Skin Carcinogenes is }}$}

Long-term skin-painting studies at PNL and ORNL utilize a protocol irvolving dermal application of test material three times per week for up to 2 years. Additionally, a shorter-term ( 6 months) initiation/promotion assay has been utilized with several coal liquefaction materials. This assay involves a single dermal application of test material followed by twice weekly application of phorbo1 myristate acetate (PMA), a known tumor promotor.

Although all process materials for each coal liquefaction process have not been evaluated for carcinogenicity, existing data from PNL and ORNL indicate that high-boiling-range materials are carcinogenic. For example, SRC-II materials boiling between 550 and $850^{\circ} \mathrm{F}$ are carcinogenic to mouse skin while SRC-II LD is not. Additionally, high-boiling range atmospheric still bottoms and vacuum still overheads from the $\mathrm{H}$-coal process are carcinogenic while the atmospheric still overheads are not. The same result is obtained whether the process is operated in the fuel oil or syncrude mode. Initiation/promotion data indicate that high-boiling EDS liquids are also carcinogenic, while the EDS naphtha fraction is not. It is noteworthy that other fossil fuel materials, such as petroleum crudes and shale oil, are also carcinogenic in long- 
term skin-painting and short-term initiation/promotion assays. However, these materials show less carcinogenic activity than do comparable high-boiling-range coal liquids.

Long-term skin-painting and initiation/promotion assays are now in progress to determine the boiling-range distribution of mutagenic and carcinogenic activity. In these studies, SRC-I and -II materials, distilled to provide $50^{\circ} \mathrm{F}$ cuts, are being evaluated for carcinogenic activity. Similar studies are planned for $\mathrm{H}-\mathrm{coa} I$ and EDS materials.

\section{Chemical Identification of Carcinogens}

The chemical identity of materials in coal liquids primarily responsibie for skin carcinogenesis is currently unkown. Data from long-term skin painting studies show that skin tumorigenesis in mice does not correlate well with the BaP, total PAH, or polar hydroxylated aromatic hydrocarbon content of coal liquids. However, skin tumorigenesis does correlate with the average molecular weight or boiling point of the material tested. Reasons for the lack of correlation between BaP content of coal liquids and observed cancers are unknown.

\section{Acute Toxicity}

Several SRC-derived materials and some $\mathrm{H}$-coal distillates have been assayed in mice and rats to determine the $\mathrm{LO}_{50}$ following oral administration (i.e., gavage). In most cases, these materials were of moderate toxicity with an $L_{50}$ of 2 to $3.5 \mathrm{~g} / \mathrm{kg}$ of body weight. Thus, acute toxicity to rodents is less than that of many materials currently in commercial use (e.g., phenol, sodium hydroxide, malathion, etc.). Dne material (SRC-I WS) contained high quantities of phenolic components and appeared to be toxic at less than $1 \mathrm{~g} / \mathrm{kg}$ of body weight. 
A number of coal-derived compounds were tested at ORNL for acute skin and ocular toxicity. None of the materials produced lethality when applied to rat skin at doses of $2 \mathrm{~g} / \mathrm{kg}$. Additionally, there was no skin sensitization, although some of the materials produced slight redness and swelling when placed on rabbit skin. Although eye irritation was noted with $\mathrm{H}$-coal and SRC materia)s, the response was reversible.

\section{Teratogenesis}

A number of natural and synthetic crude oils and raw products, including SRC-II fuel oil blend, has been tested in a frog embryo teratogenicity assay (Xenopus) developed at ORNL. Shale crudes and coal-derived liquids were teratogenic; aromatic and aliphatic petroleum crudes were not. Aqueous streams from $\mathrm{H}$-coal were toxic but not teratogenic.

The SRC-I LO, WS, and PS and the SRC-II LD, MD and HD were evaluated at PNL for potential teratogenic activity in rats. Animals were exposed ora11y over two periods of gestation. The first period was from 7 to $11 \mathrm{dg}$, when rapid organogenesis occurs and animals are often sensitive to other insults. The second period was from 12 to $16 \mathrm{dg}$, when rapid growth of organ systems occurs. Although substantial fetal mortality could be induced by administering SRC materials during 7 to $11 \mathrm{dg}$, 1ittle teratogenic effect was noted in survivors. Additionally, doses causing fetal mortality also resulted in signs of maternal toxicity.

Fetal mortalities also occurred when high levels of LD $(\geqq 0.56 \mathrm{~g} / \mathrm{kg} / \mathrm{day})$ were administered at 12 to $16 \mathrm{dg}$, although no teratogenic effects were noted. However, when SRC-I PS ( $\geqq 0.66 \mathrm{~g} / \mathrm{kg} / \mathrm{day})$ or SRC-II HD ( $\geqq 0.37 \mathrm{~g} / \mathrm{kg} / \mathrm{day})$ was administered during this gestation period, intrauterine growth was retarded and fetal deaths and abnormalities (i.e., cleft palate, hypoplastic lungs, and 
diaphragmatic hernias) were noted. Hypoplastic lungs appeared at doses of HD $(0.37 \mathrm{~g} / \mathrm{kg} /$ day) that did not produce notable maternal toxicity. Additional studies in which female rats were exposed at 12 to $16 \mathrm{dg}$ and then allowed to give birth, showed that postnatal survival was affected by even lower doses of HD. Those offspring dying during the first week after birth generally had small lungs, and it is presumed that pulmonary deficiency contributed to poor surviva1. Additional studies where pregnant rats were exposed to aerosols of SRC-II HD $(0.66 \mathrm{mg} / \mathrm{L})$ during 12 to $16 \mathrm{dg}$ also produced hypoplastic lungs and a small increase in the incidence of cleft palate in the embryos.

\section{Mamma 1 ian Mutagenesis}

Studies have also been conducted to determine if coal-derived materials are mutagenic in the whole animal. SRC-II HD, a PDU-derived liquid (Synthoil) and several of its fractions, and two PAHs (BaP and dimethylbenzanthracene [DMBA]) were evaluated using the dominant lethal test in male mice (which detects effects in postspermatogonial germ cells). BaP and DMBA were clearly active while the crude coal liquids were only slightly active. The Synthoil fractions were all negative. When these materials were subjected to the total reproductive capacity test in female mice, all were positive. Because this test, by itself, does not distinguish between dominant lethality and oocyte killing, it is not clear which mechanism is operative.

The mammalian spot test, which detects gene mutations as well as gross chromosomal damage, was positive for BaP and Synthoil, but negative for SRC-II liquid. The specific locus test, which detects and quantifies transmissible gene mutations in germ cells, was negative for both SRC-II and BaP but was weakly positive for Synthoi1. The heritable translocation test for chromosome rearrangement was negative for Synthoil and BaP. 
Another study at PNL evaluated the effect of oral and inhalation exposure to SRC-II HD on the induction of dominant lethal mutations in the male mouse. HD was administered by gavage to male, Swiss-Webster mice for five consecutive days, and the induction of dominant lethals (as indicated by early resorption of embryos) was assayed by breeding treated males to untreated females. In some replicates, a small increase in the incidence of dominant lethality was found in treated animals. However, the effect was not always reproducible. When SRC-II HD was administered by inhalation, no indication of dominant lethality was noted. These data suggest that any effect of HD on dominant lethality is small.

\section{Inhalation Studies}

Onty preliminary inhalation studies have been conducted with coal-derived materials. Exposure to SRC-I PS and SRC-II HD have been performed for up to 21 days with mice, rats and guinea pigs. A relatively high dose (greater than $0.6 \mathrm{mg} / \mathrm{L}$ ) was required to produce a reduction in weight gain in the mouse and rat. Guinea pigs were substantially more sensitive to both PS and HD and required only about 0.1 to $0.3 \mathrm{mg} / \mathrm{L}$ of material to inhibit weight gain by more than $10 \%$. Although weight gain of rats and mice was reduced during exposures to PS or HD, weight gain rapidly increased to normal following cessation of: exposure. Few other clinical effects of inhalation exposure have been noted, other than the teratogenic effect mentioned above.

Pulmonary function was studied in guinea pigs and rats exposed to SRC-I PS and SRC-II HD. These materials produced minor changes in a battery of pulmonary function tests in rats. However, guinea pigs exposed for 12 days to either PS or HD showed substantial changes in pulmonary function when challenged by a histamine aerosol. Both compliance and resistance of guinea pig 
lungs were markedly altered by inhalation exposure to PS and HD. However, the effect was short-lived, and substantial recovery occurred within 3 days after cessation of exposure.

Studies were also conducted to determine if skin exposed to HO aerosol developed tumors when treated with PMA. Mice exposed to $0.66 \mathrm{mg} / \mathrm{L}$ of HD for 3 weeks, allowed to recover for about 1 month and then subjected to dermal application of PMA developed tumors.

\section{Occupational Health and Industrial Hygiene}

Extensive occupational health and industrial hygiene progams have been designed for coal liquefaction pilot plants and proposed demonstration facilities. These programs were developed on the premise that workers at coal liquefaction facilities would be exposed to potentially toxic materials.

Coal liquefaction occupational health programs have several components: 1) engineering design and control, 2) personnel and area monitoring for pollutants, 3) education, 4) work practices, 5) personal hygiene and 6) medical surveillance.

Occupational health considerations begin with the plant design. Control of most noise, dust, gases and liquid pollutants may be achieved by appropriate facility design. For example, designs for the EDS pilot plant were reviewed by industrial hygienists to evaluate work areas and to recommend measures to decrease the likelihood of employee exposure to toxic materials.

Monitoring plant operations helps to determine actual and potential exposures to chemical and physical agents. At the SRC pilot plant at Fort Lewis, Washington, air samples were analyzed for total particulates; benzene-soluble material; several polynuclear aromatic hydrocarbons; phenols; $\mathrm{H}_{2} \mathrm{~S} ; \mathrm{SO}_{2} ; \mathrm{COS}$ and other gases; aromatic amines; organic vapors; silica; and asbestos. Addi- 
tionally, surveys were conducted to determine noise levels, lighting adequacy, and radiation levels. Results of these studies suggest minimal exposure to problematic agents in the pilot plant; they also suggest that acceptable levels could be achieved in a demonstration facility.

Monitoring instruments to detect pollutants that are immediately toxic, such as $\mathrm{H}_{2} \mathrm{~S}, \mathrm{CO}$, and $\mathrm{NO}_{x}$, are commercially available. Instruments to detect materials that present a more long-term health risk, such as PAHs, aromatic amines, heterocyclic aromatics, and nitroaromatics in the vapor phase, have also been developed but are currently not widely available. Instruments to detect the latter compounds include a pocket-sized gas chromatograph, a derivative ultraviolet (UV) absorption spectrometer, an atmospheric pressure ionization mass spectrometer, and a passive, badge-type dosimeter. A semiportable fluoroscope has also been developed to detect surfaces contaminated with fluorescing materials. While all of these pieces of monitoring equipment have been developed and tested as prototypes, none has been used extensively in the field.

Health education programs are in place at each coal liquefaction pilot plant. Participation is mandatory. Industrial hygienists emphasize potential hazards associated with the process and delineate work and personal hygiene practices that will minimize potential hazards. The need and use of protective clothing and the need for careful skin cleaning are stressed.

Medical surveillance, including a preplacement and periodic medical examination, is an integral part of the occupational health program at all pilot plants. Special attention is paid to evaluation of skin and lungs. Colored photographs are used to document skin condition at the time of employment and any changes that occur during employment. A prototype lightpipe luminoscope, which uses a lower source of incident light than most techniques, has been developed for monitoring skin. Use of the luminoscope eliminates problems that 
may develop due to synergistic actions when contaminated skin is monitored with the highly energetic incident light inherent in other types of equipment. Sputum samples are obtained for cytologic evaluation. Chest $x$-rays are taken and pulmonary function is measured. Standard blood chemistry and urinanalyses are performed.

Because work forces are small and have a limited history, the possibility of long-term effects cannot be ruled out. Nonetheless, there have been no indications of unique health problems in coal liquefaction pilot plants at this time.

of the many measures and observations made during medical examinations at the Fort Lewis SRC pilot plant, most show no differences between plant workers and controls. However, two measures have been correlated with in-plant work. The first involves deposition of black specks in the pores of the skin, particularly for those workers in the coal preparation, product solidification, solvent recovery, mineral separations and Lummus unit areas. Second, analyses of skin wash samples indicate recovery of more HD material from workers in these areas. There appears to be a rough correlation between black speck severity and the amount of material recovered by skin washing.

Occupational health programs at coal liquefaction facilities should continue with periodic review to determine their effectiveness and to identify any additional requirements. Retention of workers' records and follow-on studies after termination of plant operations will be performed.

\section{Effects of Potential Ameliorative Actions on Chemical Composition/Biological} Activity

The relatively high biological activity of coal liquids compared to shale oils and crude petroleums has generated interest in evaluating methods to mod- 
ify chemical properties to reduce or eliminate genotoxic and carcinogenic potential and systemic toxicity. Both hydrotreatment (i.e., addition of hydrogen) and controlled fractional distillation are being evaluated.

\section{Hydrotreatment}

Studies at ORNL with a PDU-derived H-coal distillate and at PNL with an SRC-II distillate blend indicate that experimental-scale hydrotreatment can be effective in reducing or eliminating the genotoxic activity of coal liquids. Ames assay of the H-coal distillate that had undergone three levels of hydrotreatment ( 1 ight, medium and heavy) showed that heavy hydrotreatment eliminated mutagenic activity; light and medium hytrotreatment had little demonstrable effect. Ames assay of the SRC-II distillate blend that had undergone two levers of hydrotreatment (i.e., moderate at 1290 standard cubic feet [SCF] of hydrogen per barrel and severe at 1870 SCF of hydrogen per barrel of coal liquid) showed that both hydrotreatment levels reduced mutagenicity about 100fold (from 1.20 to $0.01-0.03$ revertants $/ \mu g$ of fractionated material).

Hydrotreatment had a marked effect on chemical composition of the distillate blend. Hydrotreating reduced the aromatic, phenolic, PNA, nitrogen heterocycle, and PAA content and increased the hydroaromatic content of the distillate blend. Both moderate and severe hydrotreatment reduced PAA levels at least 340-fold, from $1900 \mathrm{ppm}$ to concentrations that were below the 1 imits of detection. The corresponding reduction in genotoxic activity is believed to be due to the decrease in PAA concentration. No other class of compounds was reduced enough to account for the alteration in mutagenic activity.

Hydrotreatment also decreased activity in the SHE cell transformation assay by 25 to $40 \%$. Moreover, impairment of cell growth was reduced as severity of hydrotreatment increased. 
Skin-painting studies with hydrotreated $\mathrm{H}$-coal liquids showed that carcinogenicity was also substantially reduced (>50\%). Similar results have been reported for shale oil. These data suggest that some biological effects of coal liquids can be ameliorated by hydrogenation. However, while minimal hydrotreatment reduced the carcinogenic effects of PDU-derived H-coal materials, as levels of hydrotreatment were increased sufficiently to noticeably affect mutagenicity in the Salmonella assay, levels of mammalian systemic toxicity increased. If this effect is confirmed and extended to other coal liquids, the implications are to do the minimal hydrotreatment necessary to achieve satisfactory physical and chemical requirements and reduction of skin carcinogenic potential. However, the decision to use this type of treatment must also be based on engineering, economic and other factors.

\section{Fractional Distillation}

The biological activity of coal liquids tends to increase with boilingpoint (i.e., molecular weight). H-coal samples representing heavy still bottoms showed higher mutagenic activity than still overhead samples. Chemical and biological examination of SRC-I and -II boiling-point cuts of full-boilingrange materials showed that mutagenic activity was absent below $725^{\circ} \mathrm{F}$. Some activity was detected in the 725 to $750^{\circ} \mathrm{F}$ temperature range for SRC-II materials. Mutagenicity increases with temperature from 750 to $850^{\circ} \mathrm{F}$ and then decreases slightly in the still-bottoms material above $850^{\circ} \mathrm{F}$. Corresponding changes in chemical composition also occur in heavier, high-boiling-range materials. Both SRC-I and -II materials showed decreasing concentrations of aliphatic hydrocarbons with increasing boiling point. There was a corresponding increase in polycyclic aromatic hydrocarbon content. This increase occurred in the neutral, hydroxylated, and nitrogen-containing PAH fractions of SRC-II 
material. However, this increase was seen only in the hydroxylated and nitrogencontaining PAH fractions of SRC-I material. The PAAs behave in the same fashion as PAH material containing nitrogen and increase in concentration with boiling point. Again, treatment of high-boiling-range genotoxic materials with nitrous acid reduced the concentration of PAAs and lowered mutagenicity. These data indicate that increasing mutagenicity with increasing boiling point is most likely due to increasing concentration of higher-molecular-weight PAAs (with four- to five-ring systems) in higher temperature boiling-point cuts.

Knowledge of the temperature ranges at which biologically active constituents occur may be a factor in selecting the temperature range of potential commercial products to minimize potential toxicity. For example, distillate cuts from the SRC-II process showed mutagenic activity in the Ames assay at about 720 to $725^{\circ} \mathrm{F}$. Based on a proposed distillation curve for "percent ma" terial distilled" versus "temperature" for a projected demonstration-scale facility, $720^{\circ} \mathrm{F}$ corresponds to a distillation of about $80 \%$ of the full-boilingrange material. Thus, a product distilled at $725^{\circ} \mathrm{F}$ might be handled with no additional concern for mutagenic effect. The remaining $20 \%$ of the full-boilingrange material could be subjected to additional treatment, perhaps hydrotreatment, before being shipped offsite, or it could be restricted to use onsite.

\section{Part (3): Ecological Fate and Effects}

This section summarizes available laboratory and field data on the fate of coal liquefaction products, process and waste materials released to the environment, effects of these materials and their transformation products on terrestrial and aquatic systems, and the potential for food chain transfer of coal liquefaction residues to man. 


\section{Terrestrial Fate and Transport}

Nonoccupational health effects associated with coal liquefaction operations will be influenced by environmental factors that govern the form, transport and persistence of coal-derived materials and wastes in terrestrial and aquatic systems and that mediate exposure to man. The research described below was conducted to determine the fate of constituents in spilled liquid product and process wastes and disposed oily sludges and solid wastes, and focuses on water-soluble, persistent materials with greatest potential for mobility and incorporation into water, soils, sediments and human food supplies.

A series of soil sorption studies were initiated with aniline and phenol to define the fate of components of coal liquids in terrestrial habitats. These compound types account for the majority of water-soluble organics in an SRC-II distillate blend (MD:HD). Results of these studies suggest that, under spill conditions, certain soils of the eastern coal region (Westmorland silt loam) may significantly retard the movement of organic nitrogen bases (anilines), while phenols remain relatively mobile. Thus, phenols would likely be the first compounds to have an impact on ground water quality. In contrast, the primary environmental impact of anilines may result from plant uptake and subsequent food chain incorporation and transport. Additional studies are currently in progress to determine the effects of microbial interaction on persistence of both free and sorbed anilines and phenols in soils.

Comparative degradation studies were conducted with a petroleum crude, shale oil and coal liquid added to laboratory soil columns at $16 \mathrm{mg} / \mathrm{g}$ dry soil (saturation). Numbers of oil-degrading microorganisms increased significantly in soils following addition of the petroleum crude or shale oil. However, microorganisms that degrade coal liquids were undetectable both at the start of the experiment and 3 months later. These results suggest that phenolic or 
other compounds in coal liquids are highly toxic to microorganisms, and coal liquids may eradicate microbial communities that aid in the degradation of heavier hydrocarbons. Thus, coal liquids may remain in the soil for longer periods of time than petroleum or shale oils. When phenolics and other toxic compounds decrease to concentrations at which microorganisms that metabolize hydrocarbons survive, biodegradation of spilled coal-derived materials will occur. However, the timing of this process will likely depend on several factors including: magnitude of the spill, ambient temperature, rates of leaching, and other site-specific features. Lysimeter studies confirm that coal liquids do not readily degrade. Although germination of barley (Hordeum vulgare) occurred during the second growing season following contamination of soils with an SRC-II coal liquid ( 1.48 to $14.84 \mathrm{~L} / \mathrm{m}^{2}$ of soil), grain production was still significantly reduced at all test concentrations.

Studies were performed with a nongasified SRC-I mineral residue (this material will probably be gasified at a commercial facility) to evaluate methods to characterize aqueous leachates from coal-derived solid wastes and to identify specific chemical and mineralogical properties of the mineral residue that may influence physicochemical composition of the gasified mineral slag. The SRC-I mineral resjdue contains pyrrhotite, a crystallographically complex iron sulfide. Aqueous column leachates of this material were slightly basic ( $\mathrm{pH}$ 8.0-8.4) and contained notable quantities of soluble salts $\left(\mathrm{Na}^{+}, \mathrm{Ca}^{+}{ }^{+}, \mathrm{Cl}^{-}\right.$, $\mathrm{SO}_{4}{ }^{-}$), boron, strontium, fluoride, and organic carbon.

Biological transport studies were conducted to determine the capacity of terrestrial plants to absorb respresentative SRC components (aniline and phenol), and to elucidate their chemical fate as either a parent compound or decomposition product resulting from plant metabolism. Studies with hydroponi- 
cally grown soybeans showed phenol and anitine induced severe phenotypic and toxicity responses at concentrations in excess of 50 and $10 \mathrm{mg} / \mathrm{L}$, respectively.

Subsequent studies were conducted with ${ }^{14} \mathrm{C}-1$ abeled aniline and phenol to obtain data on absorption rate, plant distribution, and chemical fate. Plant absorption rate for ${ }^{14} \mathrm{C}$-aniline was substantially lower than for ${ }^{14} \mathrm{C}$-phenot. Unlike phenol, aniline established a strong tendency to sorb to cell wall materials which resulted in uncertain absorption ratios. Also, less ${ }^{14} \mathrm{C}$-aniline than phenol was metabolized to higher-molecular-weight components. These data suggest that aniline is more persistent than phenol. In general, these studies demonstrate a complex interaction among organic pollutants entering the food chain and emphasize the need to evaluate specific components of coalderived materials for both bioavailability and chemical fate. Obvious differences in the phytotoxicity, absorption and chemical fate of phenol and aniline suggest the need for a tiered screening approach to identify specific pollutants of concern and institute procedures to ameliorate their environmental impacts.

Laboratory experiments have also been conducted to determine if plants can assimilate a PAH, anthracene, from the environment and to determine its potential for accumulation and catabolism. Studies with one-week-old soybean plants have utilized ${ }^{14} \mathrm{C}$-anthracene in nutrient solution, moist and flooded soil, and the atmosphere. Results indicated that ${ }^{14} \mathrm{C}$-anthracene was taken up from either roots or foliage, translocated, and catabolized to lower-molecularweight by-products. Uptake rates from the soil were generally proportional to anthracene concentration and were lower from soil than from nutrient solution. These experiments indicate that the potential for PAH compounds to accumulate in vegetation exists and should be considered in short- and long-term analysis 
of risks from synfuels production. Additionally, these results suggest that food chain accumulation of hydrocarbons may occur and should be evaluated.

\section{Terrestrial Effects}

Operation of coal liquefaction facilities will result in localized environmental releases of gaseous sulfur species not presently regulated by air quality standards. Hydrogen sulfide $\left(\mathrm{H}_{2} S\right)$ and carbonyl sulfide (COS) are among the more quantitatively significant sulfur species anticipated. Research now in progress is designed to evaluate the comparative phytotoxic effects of these gaseous sulfur species relative to sulfur dioxide, the major sulfur gas released from conventional coal combustion facilities, or from combustion tail gases from a coal conversion facility.

Current research also addresses the potential for effect if coal-derived liquids are spilled during transport. Such spills could contaminate surface waters and soils, possibly causing acute and chronic damage to plants and animals, and increase the potential for synfuel residues to enter food chairis leading to man.

Sulfur-containing gases that are common stack emissions during liquefaction will occur as both reduced ( $\mathrm{COS}, \mathrm{H}_{2} \mathrm{~S}$, carbonyl disulfide $\left[\mathrm{CS}_{2}\right]$, and methy mercaptan $\left[\mathrm{CH}_{3} \mathrm{SH}\right]$ ) and oxidized (sulfur dioxide $\left[\mathrm{SO}_{2}\right]$ ) forms. Toxicity of liquefaction-emission products to vegetation is a function of deposition rate on foliage and subsequent disruption of metabolic processes. At equivalent ambient concentrations, the principal sulfur gases from liquefaction react with vegetation at rates that vary 10-fold. Reactivity of the gases in descending order is:

$$
\mathrm{SO}_{2} \geqq \mathrm{H}_{2} \mathrm{~S}>\mathrm{COS}>\mathrm{CH}_{3} \mathrm{SH} \geqq \mathrm{CS}_{2}
$$


Over a range of concentrations $(0.25$ to $0.5 \mathrm{ppm}), \mathrm{SO}_{2}, \mathrm{H}_{2} \mathrm{~S}$, and $\mathrm{COS}$ depressed photosynthesis below that of controls, while $\mathrm{CS}_{2}$ and $\mathrm{CH}_{3} \mathrm{SH}$ had no influence on photosynthesis. The relative toxicity of these gases follows the same order as that cited above for reactivity. The correlation between reactivity and toxicity suggested that the former may be a screening tool from which to gauge the potential impact of any coal conversion gas. Differences in molecular size of the gases and their solubilities in water accounted for $86 \%$ of the variation in gas reactivity.

The utility of this screening technique was demonstrated with the several representative light hydrocarbon gases emitted during liquefaction. Exposure of Bush Blue Lake Bean (Phaseolus vulgaris L.) to $5 \mathrm{ppm}$ of 10 hydrocarbons separately for 4 hours did not produce any visible signs of chlorosis/necrosis or elicit any change in productivity. The absence of any effect was not unexpected based on properties of water solubility and molecular size that contributed to relatively low bioavailability. When these properties for each hydrocarbon were used as the variables to predict flux, only 3 to 10 hydrocarbons showed any appreciable rate of reaction with vegetation, and the three most reactive gases (ethylene, butane and propane) had flux rates well below any of the sulfur-containing gases.

Climate also influences plant response to pollutants, and relative humidity is a major controlling factor. In a comparison of ozone or $\mathrm{SO}_{2}$ uptake by vegetation in dissimilar humidity environments, uptake at $70 \%$ relative humidity was 200 to $300 \%$ higher than that recorded at $35 \%$ humidity. Thus the impact of emissions from liquefaction may vary as a function of the region in which the facility is located.

The presence of other pollutants in the atmosphere also affects plant response to liquefaction-emission products. Although nitrogen oxides are re- 
leased from process-fired heaters, boilers, calciners, and controlled combustors during liquefaction, there is a low probability of adverse effects on vegetation since emission levels are low. However, when nitrogen oxides occur with $\mathrm{SO}_{2}$ (a liquefaction emission) at concentrations above $262 \mu \mathrm{g} / \mathrm{m}^{3}$ and ozone (a regional pollutant in the eastern United States) the growth of vegetation is depressed significantly. Thus the potential impact of emissions must be gauged within the context of multiple-pollutant, site-specific exposures. Therefore, interaction studies involving combinations of pollutants from coal liquefaction processes and background pollutants, such as ozone, are important to predicting effects under siting conditions in the northeastern United States. Regional studies which involve modeling pollutant dispersion from multiple technologies are under way to identify likely combinations and concentrations of pollutant gases and to provide a framework for multitechnology siting decisions.

Studies with barley (Hordeum vulgare) exposed to SRC-I solids added to soils in outdoor lysimeters showed little effect on germination, growth, or yield when soil and SRC-I solids were mixed $1: 1$. When the barley was grown on a 3-dm layer of soil placed over a $1-d m$ layer of SRC-I, growth and yield were reduced, apparently because of the inability of roots to penetrate the SRC-I layer. SRC-II liquids added to the soil layer 10-dm below the surface produced lesions, chlorosis, and necrotic tissue at concentrations of $1.48 \mathrm{~L} / \mathrm{m}^{2}$ and $14.8 \mathrm{~L} / \mathrm{m}^{2}$. These concentrations also resulted in reduced grain yields and in grain with higher nitrogen content. However, yields increased during the second growing season following soil amendment, suggesting a decrease in toxicity because of microbial degradation and other processes.

Studies have also been conducted on the effects of synfuel materials on insect reproduction. In experiments to determine effects of azaarenes (a constituent of coal liquids) on egg production and hatching success in crickets, 
an increased frequency of morphologic abnormalities was observed in developing embryos. Additionally, several coal liquids were found to be potent teratogens; eggs developing in soil contaminated with coal-derived materials may produce nymphs with extra antennae, eyes, or heads. Results of standard mammalian teratogenesis assays confirm the teratogenic potential of coal liquids. Petroleum products do not cause these developmental abnormalities.

The teratogenic properties of coal liquids are also being investigated using bioassays of cherically derived fractions. Most of the teratogenic activity of coal liquids appears to reside in the ether-soluble base fraction which consists of aromatic amines (many of which are carcinogenic) and azaarenes. This suggests that removal of nitrogen compounds by hydrotreatment or other options may reduce the teratogenic activity of coal liquids.

\section{Aguatic Fate and Transport}

Based on statistics from the petroleum industry, the potential exists for coal liquids to be spilled during transport and subsequently to enter surface waters. Laboratory tests on a variety of organisms (phytoplankton, invertebrates, fish) show that coal liquids are generally more toxic to aquatic organisms than comparable petroleum products. Coal liquids contain relatively high concentrations of phenols which are acutely toxic to aquatic organisms at the $\mathrm{mg} / \mathrm{L}$ level and the potential exists for certain components (polycyclic and nitrogen-containing polycylic aromatic hydrocarbons) to enter aquatic food chains leading to man. Levels of toxicants and their degradation rates in surface waters must be determined to assess more fully the potential effects of spilled coal liquids. Studies described below focus on determining levels of solubilized contaminants and rates of dissolution/degradation as a function 
of oil composition and important environmental variables such as evaporation, photolysis, emulsification, sedimentation, etc.

To characterize the water-soluble fractions (WSFs) of coal liquids, the composition of the water-soluble nitrogen compounds were investigated. Alkyl anilines and pyridines were identified in SRC-II distillate and shown to be significant components ( 5 to $10 \%$ ) of the WSFs.

The dissolution rates of five other synthetic oils (ranging from a heavy syncrude to LD) were compared to a petroleum crude. The water-solubie contaminants from all five synthetic liquids were quite similar, although concentrations varied widely among oils. As expected, major water-soluble contaminants were phenols and cresols with lower levels of xylenols, and C3- and C4substituted phenols. Total concentrations of phenolics ranged between 50 and $250 \mathrm{mg} / \mathrm{L}$ after 48-hour equilibration. Major neutral components were toluene, xylene, and naphthalene at concentrations of 5 to $20 \mathrm{mg} / \mathrm{L}$. Basic consituents were aniline and $\mathrm{Cl}$ - to $\mathrm{C} 3$-substituted aniline at concentrations of 0.2 to 4 mg/L. Larger multi-ring compounds (naphthol, alkylnaphthalenes, pyridines and anilines) were not found at levels above detection limits $(\sim 0.1 \mu \mathrm{g} / \mathrm{L})$. No phenols or bases (except anilines) were detected in water extracts of the petroleum crude. Rates of dissolution of synthetic crude oils followed empinical predictions; phenol dissolved most rapidly while the less water-soluble contaminants dissolved more slowly. Dissolution rates were dependent on oil viscosity; the time required to reach $50 \%$ dissolution of phenol varied from 6 minutes for the nonviscous, refined distillate to more than 2 hours for the highly-viscous, heavy syncrude.

Studies were conducted to characterize water-soluble photo-oxidants produced by suntight in water underlying coal liquids, and to determine their biological activity. Rates of photo-oxidant formation from four coal Tiquids 
were nearly identical and were about one-fourth the rate of formation of photooxidants from a petroleum diesel oil. Most of the water-soluble photo-oxidant from coal liquids appeared to be hydrogen peroxide. The remainder appeared to be hydroquinine, an $\mathrm{N}$-containing phenol that is highly toxic to aquatic organisms. Toxicity to Daphnia magna of the water underlying one coal liquid doubled over 4 days illumination by sunlight; in contrast, water under a diesel oil became four times more toxic during the same length of exposure.

The fate and transport of PAHs were studied in terms of the rate and extent of photolysis (breakdown by sunlight), volatilization, sorption to particles and sediments, and microbial degradation in water and sediments. Results indicated that volatilization decreased rapidly with increasing molecular size of PAH. Photolysis increased for most of the larger potentially carcinogenic PAHs.

Microbial transformations in water were extremely slow for PAHs larger than naphthalene (two rings), even in highly polluted environments. Sediment microbial transformation rates appeared directly related to the amount of PAHs entering the water. Transformation rates were sufficiently slow for larger PAHs, such as BaP, that levels of PAH in contaminated sediments will likely remain high for several years after release. Sorption of PAHs to particles was rapidly reversible, and resuspension of sediments during high water periods may result in release of sediment-bound PAH into overlying waters.

A model has been developed describing the dissolution of compounds from a floating oil film into the underlying water. $0 i 1$ viscosity, solute oil-water partition coefficient, and aqueous phase mixing are major determinants of dissolution mass flux. The dissolution mass transfer model has been applied as a component of a one-dimensional mathematical model to predict the spatial and temporal distribution of compounds that would enter a river from a coal liquid 
spill. The river model also considers spill spreading and hydrodynamic dispersion. In the simulation, a point discharge of synthetic oil is permitted to spread across the river in accordance with gravitic, inertial, viscous, and surface tension forces, while moving downstream with river flow. Compound dissolution is described by the mass flux submodel. Once in the water column, compounds disperse because of hydrodynamic turbulence. The model will be useful in planning spill response measures, and in assessment of hazards resulting from synfuel spills into rivers.

\section{Aquatic Effects}

Studies described below were designed to evaluate potential acute and chronic effects to aquatic organisms of coal liquefaction materials, selected chemical fractions, and/or specific compounds and reference commercial oils. Test species represented various trophic levels and a variety of freshwater habitats. Toxicity test protocols were designed to 1) biologically screen raw coal-derived liquids and chemical fractions, and 2) provide a reference data base likely to be required for generic environmental impact statements and various federal and 5 tate permits.

Both PNL and ORNL have developed a battery of acute and chronic toxicity tests using aquatic organisms. Acute bioassays with algae, daphnids, chironomids, and fish have been used to compare the toxicities of WSFs of nearly 30 natural and synthetic oils. Crude and hydrotreated shale oils were more toxic than petroleum equivalents; however, hydrotreated shale oil was less toxic than the crude shale oil. Coal liquids (SRC-I, -II and H-coal [raw distillate, or fuel oil blend]) were all 10 to 1000 times more toxic than comparable petroleum products. 
Phenols were responsible for much of the toxicity of coal liquid WSFs. Aromatic hydrocarbons, the major toxic constituents of WSFs of petroleum, had a negligible influence on the toxicity of WSFs of coal liquids. Partial removal of phenols by hydrotreatment of crude coal liquids reduces the solubility and toxicity of these oils. Also, hydrotreatment at the production site may lessen the potential environmental hazards associated with product storage and transport. Control technology options, including hydrotreatment, are currently being investigated.

In chronic exposure studies, biological effects were compared using "fresh" and "weathered" WSFs. Organisms were exposed to the WSF from an initial-contact with water and to a WSF derived from a water-leached coal liquid. Lower molecular weight phenols predominated in the initial-contact WSF, while relatively higher molecular weight phenols and hydrocarbons characterized the water-leached WSF. Based on percent dilution, the initial-contact WSF was more toxic to all organisms tested than the WSF derived from the water-leached material. However, in bioassays of chironomid larvae (Chironomus tentans and Tanytarsus dissimilis), the water-leached WSF was more toxic than the initial-contact WSF when equal concentrations of total organic carbon (TOC) were present. For Daphnia magna, the initial-contact WSF was more toxic than the water-leached WSF. Although the two WSFs were similar in toxicity to algae (Selenastrum capricornutum) over a five-day exposure period, the ability of algae populations to recover to control levels was suppressed to a greater extent in the water-leached WSF. Coal liquids spilled in aquatic habitats will be absorbed on suspended particulates and be deposited in sediments. To provide information on processes governing retention of coal liquids, and particularly the phenolics in aquatic systems, Columbia River fine sediments were artificially contaminated with two concentrations (20 and $50 \mu \mathrm{L}$ SRC-II liquid/120 g wet sediment) and 
subjected to a series of repeated mixing and water replacements to simulate natural river scouring. Adult daphnids and chironomid larvae were used as biological indicators of toxicity in the water column and sediments, respectively.

Chemical characterization of test systems showed that readily watersoluble phenolics were rapidly removed from the contaminated sediments. Re:moval rates of total phenolics were linear for both concentrations tested. Rate of removal was dependent on compound class $(\mathrm{C} 1, \mathrm{C} 2, \mathrm{C} 3, \mathrm{C} 4$ phenols $>\mathrm{Cl}$, C2 indanols > phenol > C3 indanols). Sediment retention of less soluble, heavy-molecular-weight phenolics affected behavior and survival of sedimentdwelling organisms (chironomid larvae) after acutely toxic effects were no longer observed for daphnids residing in the water column. These studies suggest that as soluble phenolics are leached from sediments contaminated with coal liquids, pelagic organisms will be exposed to toxic components over reiatively short time periods, but that insoluble components remaining in sediments can result in long-term toxicity to benthic organisms.

\section{Ecosystem Studies}

The potential impacts of synfuel spills can only be examined completely when the responses of integrated ecosystems are considered. This "systemlevel" approach is frequentiy ignored in hazard assessment. Mathematical models are one means of integrating individual processes to simulate ecosystem interactions; laboratory microcosms or model ecosystems are another. A pond microcosm has been developed at ORNL. An experimental stream system has been developed at PNL.

Pond microcosm experiments were conducted with the WSF of an SRC-II dis-

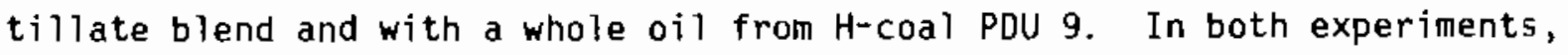


relatively low doses of coal liquid (equivalent to 0.1 of the $48-\mathrm{hr}$ LC $_{50}$ for Daphnia magna) caused extensive changes in community structure and function. Many zooplankton species were eliminated and diatoms were replaced by bluegreen algae. Patterns of community metabolism were also affected. That is, detritus (dead algae) replaced diatoms and other algae as a food source for zooplankton. However, eliminating toxic input resulted in a partial recovery of the system. 



\section{RISK ASSESSMENT}

Health and environmental risk assessment is an integral part of DOE's overall coal liquefaction program and serves to integrate the many separate research and development functions in an attempt to quantitatively assess potential human health and ecosystem effects. The assessment incorporates basic information concerning source terms, exposure mechanisms, dose-risk relationships and uncertainty. Because they are conducted on a regional or national scale, concentrating on muttiple facilities representing a mature industry, the analyses are not intended to compete with or replace the need for sitespecific environmental impact statements.

Source terms are rarely precise, exposure-dose relationships are not fully understood, and the numbers of workers or members of the public exposed to pollutants are often not we 11 known. These and other factors produce uncertainty in the final estimates of health and environmental risks. Characterization of the uncertainty is important and should be incorporated in the analysis. By identifying areas of uncertainty, it is possible to manage a program of health and environmental research focused on providing information required to reduce the uncertainty in these critical areas.

The coal 1 iquefaction risk analysis can be divided into four parts. First is the occupational risk in building a coal liquefaction facility and supplying the required coal. Preliminary results suggest that this source may be a significant part of overall risk. Although sometimes not included in risk analyses, the "front-end" of the fuel cycle should be included if we are to understand the total risk to human health and the environment. Second are health effects to the occupational work force in and around an operating facility. Third are health effects to the public. Fourth is the environmental risk to nonhuman species. 
Knowledge of source terms for various chemical pollutants emitted to air and water is essential to assess the last three sources of risk. Although precise values for each of the emissions from a coal liquefaction facility that can affect human health cannot be specified, a crude estimate of these releases has been developed".

Data on regional weather patterns have been used to investigate and evaluate atmospheric dispersion and multiple-facility interactions. A set of generic atmospheric dispersion factors has been employed to evaluate potential health risks associated with airborne pollutants. There are also many other factors that must be considered in one or more aspects of risk analysis including: persistence of pollutants, their solubility in water, pathways of human intake, uptake of synfuel residuals by crops, ground-water movement, toxicity, and epidemiology. An iterative process of risk analysis can help in planning the direction of health and environmental research programs so that they provide the information needed to understand and lower the uncertainties in the assessment. 


\section{RISK ASSESSMENT}

Health and environmental risk assessment is an integral part of DOE's overall coal liquefaction program and serves to integrate the many separate research and development functions in an attempt to quantitatively assess potentia] human health and ecosystem effects. The assessment incorporates basic information concerning source terms, exposure mechanisms, dose-risk relationships and uncertainty. Because they are conducted on a regional or national scale, concentrating on multiple facilities representing a mature industry, the analyses are not intended to compete with or replace the need for sitespecific environmental impact statements.

Source terms are rarely precise, exposure-dose relationships are not fully understood, and the numbers of workers or members of the public exposed to po1lutants are often not well known. These and other factors produce uncertainty in the final estimates of health and environmental risks. Characterization of the uncertainty is important and should be incorporated in the analysis. By identifying areas of uncertainty, it is possible to manage a program of health and environmental research focused on providing information required to reduce the uncertainty in these critical areas.

The coal liquefaction risk analys is can be divided into four parts. First is the occupational risk in building a coal liquefaction facility and supplying the required coal. Preliminary results suggest that this source may be a significant part of overall risk. Although sometimes not included in risk analyses, the "front-end" of the fuel cycle should be included if we are to understand the total risk to human health and the environment. Second are health effects to the occupational work force in and around an operating facility. Third are health effects to the public. Fourth is the environmental risk to nonhuman species. 
Knowledge of source terms for various chemical pollutants emitted to air and water is essential to assess the last three sources of risk. Although precise values for each of the emissions from a coal liquefaction facility that can affect human health cannot be specified, a crude estimate of these releases has been developed.

Data on regional weather patterns have been used to investigate and evalvate atmospheric dispersion and multiple-facility interactions. A set of generic atmospheric dispersion factors has been employed to evaluate potential health risks associated with airborne pollutants. There are also many other factors that must be considered in one or more aspects of risk analysis including: persistence of pollutants, their solubility in water, pathways of human intake, uptake of synfuel residuals by crops, ground-water movement, toxicity, and epidemiology. An iterative process of risk analysis can help in planning the direction of health and environmental research programs so that they provide the information needed to understand and lower the uncertainties in the assessment. 


\section{RESEARCH AND ASSESSMENT NEEDS}

This report has summarized the health and environmental data base currently available for direct coal liquefaction. To evaluate the existing data base and recommend future research directions for health and environmental studies relative to coal liquefaction and gasification, staff representing DOE, PNL, ORNL, Argonne National Laboratory and the Inhalation Toxicology Research Institute met in Airlie, Virginia January 26-28, 1982. Topics discussed included chemical characterization, hea1th effects, industrial hygiene, ecological fate and effects and risk assessment. The following summarizes areas where further health and environmental research is required for coal Tiquefaction.

\section{Chemical Characterization and Health Effects}

\section{Development of Improved Short-Term Bioassays}

Improved short-term bioassays should be developed that are appropriate for complex mixtures. Additionaliy, many whole-animal, short-term tests require further evaluation. These include the lung adenoma test and a variety of quantitative screens to detect genetic damage in mammalian DNA.

\section{Identification of Causative Agents}

Further research is needed to jdentify the specific mutagens and carcinogens in potential products from direct coal liquefaction processes currently under development. Additionally, the chemical characteristics and potential biological activity of indirect liquefaction materials should be evaluated. Studies to evaluate interactions among components of coal liquefaction mix- 
tures and how these interactions influence biological activity need to be initiated.

\section{Extrapolation from Whole-Animal Test Systems to Man}

Data obtained in experimental animals must be extrapolated to man to assess potential health effects. Because substantial uncertainty exists concerning the use of animal data in assessing risk to man, improved extrapolation methods need to be developed.

\section{Effect of Process/Product Modifications}

Additional studies are needed to determine the effects of: 1) process conditions, 2) product upgrading treatments, and 3) control technologies on potential health effects. The relationship between precise chemical structure and ohserved biological effect should be studied to allow development of process engineering designs that can be implemented to ameliorate biological activity of coal-derived products. Synthesis of precise chemical isomers is needed to identify unknowns in complex mixtures and to assess the effect of isomeric placement of ring-substituent groups on biological activity.

\section{Inhalation Studies and Pulmonary Physiology}

Inhalation is a major pathway for exposure to coal liquefaction materials. The use of patho-physiological techniques needs to be focused especially on mechanisms causing long-term lung damage. A number of pathologic conditions in humans involve altered pulmonary function (e.g., emphysema, silicosis, and other fibrotic diseases). The effect of inhaled coal-derived materials on this end point should be determined. 


\section{Factors Affecting Dermal Carcinogenicity}

Because skin contact will be a primary route of worker exposure to coal liquefaction materials, it may be necessary to examine factors that affect the carcinogenic process. For example:

- Dose Fractionation. Current experimental evidence for carcinogenicity is based on continuous application of coal liquids to mice for a prolonged period. Since this is not representative of potential human exposure, information is required on effects of doses administered singly, staggered over varying time frames, and doses mixed from various process streams.

Removal of Dose from Skin. A common industrial hygiene practice in coal facilities is to remove skin contamination with detergent and water. The efficacy of these procedures has not been fully estabiished. Alternate washing/solvent regimes should be analyzed for their effectiveness in ameliorating dermal carcinogenicity.

- UV Light Exposure. Workers at coal conversion facilities will be exposed both to skin contamination and UV light. Effects of combined exposure to UV light and coal liquefaction materiais should be evaluated.

- Preventive Treatment. Several materials inhibit skin carcinogenicity from pure chemicals. Their effectiveness for inhibiting skin carcinogenicity from coal liquids should be examined. 
Dosimetry

Information is needed on absorption, tissue distribution and excretion of important compounds, particularly PNAs, PAAs and $\mathrm{N}$-heterocycles to relate biological effects to causative agents. This includes knowledge of pharmacokinetics, and metabolism of toxicologically active constituents in coal liquefaction materials.

\section{Identification of Sensitive Populations}

Populations that may be especially sensitive to coal liquefaction materials (e.g., pregnant females) should be identified and appropriate studies initiated.

\section{Epidemiologic Studies}

There is, at this time, no plan for epidemiologic studies on workers at existing or planned coal liquefaction facilities. Although current worker populations are small, they will increase, and plans for such studies should be developed and attempts made to provide consistent data collection and ana 1yses.

\section{Cardiovascular Effects}

Studies are needed to determine the effects of coal liquids on the cardiovascular system.

\section{Degenerative Diseases}

Studies are needed to determine the effects of coal liquids on the incidence and severity of degenerative diseases of the immune, hematopoietic, central nervous and renal systems. 


\section{Monjtoring Equipment}

Equipment for the real-time monitoring of particulate PAH contamination and for detecting the vapors of multi-ring PAHs in the workplace is needed. Most high-boiling constituents of coal liquids will likely be present as aerosols while the smaller-ring constituents will predominate as vapors.

\section{Ecological Studies}

\section{Terrestrial Effects}

Further studies are needed to determine acute and chronic effects of varjous coal liquefaction materials on economically and ecologically important plant and animal species. Principal toxic components need to be identified, and the effects of process control options (hydrotreatment) on residual tox-: icity need to be determined. Field experiments in lysimeters, soil plots and open-top chambers need to be conducted to verify, refine, and extend laboratory results and model predictions concerning the transport, fate, and effects of solid waste leachates, spilled coal liquids, and gaseous emissions.

\section{Aquatic Effects}

Further studies are needed to determine the acute and chronic effects of coal liquids and waste streams on ecologically important species. Principal toxic constituents need to be identified and effects of process control options (hydrotreatment, biodigestion) on residual toxicity need to be determined. Field experiments (microcosm, model pond and stream) are required to

verify, refine, and extend laboratory results and model predictions concerning fate, transport, and effects of spilled products and waste streams. 


\section{Terrestrial Fate and Transport}

Atmospheric emissions need to be characterized with respect to speciation and ground-leve 1 concentrations. Interactions with other atmospheric contaminants need to be studied, and atmospheric transport and transformations need to be modeled on a local and regional basis. Leaching from sludge, gasified mineral slag, and other solid waste forms needs to be characterized, quantified, and modeled. Additionally, assimilation, metabolism, and elimination of residues from coal liquids, atmospheric emissions, and solid wastes in terrestrial food chains leading to man need to be quantified and modeled.

\section{Aquatic Fate and Transport}

Physical, chemical, and biological processes governing dispersal of synfuel materials released to water and sediments need to be evaluated. Dissolution, evaporation, emulsification, photodegradation, sedimentation, and biodegradation of spilled synfuel materials need to be quantified and modeled.

Residues in water sediments and biological tissues need to be characterized and quantified. Biological transfer studies are needed to evaluate the potential for synfuel residues to enter aquatic food chains and accumulate, or concentrate through food chains and increase the risk to man. Modeling of environmental pathways is required to assess the relative importance of major routes by which man or other organisms may be affected by synfuel residuals, and ultimately, to predict levels of exposure to man and his resource organisms.

\section{$\underline{\text { Risk Assessment }}$}

A comprehensive risk analysis on a large-scale coal liquefaction industry should continue to assist in formulating and managing the health and environ- 
mental research programs. The analysis should encompass an assessment-oriented technology description, chemically and physically characterized source terms, environmental transport and fate modeling, and ecological and human health effects modeling. Additionally, methods should be developed to characterize uncertainties in the risk-assessment process, to conduct a probabilistic risk assessment, and to estimate toxicologic potency and extrapolate across species and levels of biological organization. 



\section{BIBLIOGRAPHY OF OIRECT-COAL-LIQUEFACTION-RELATED HEALTH AND ENVIRON- MENTAL EFFECTS RESEARCH}

Auerbach, S. I. and D. E. Reichle. 1982. Environmental Sciences Division Annual Progress Report for the Period Ending September 3D, 1981, ORNL-590D, 0ak Ridge National Laboratory, Oak Ridge, TN, 208 p.

Bean, R. M., C. D. Becker, J. R. Skalski, W. E. Fallon, A. J. Scott, K. Shiosaki, and B. W. Wilson. 1982. Aqueous suspensions of solvent-refined coal liquids: Effects of preparation procedure on chemical composition and toxicity, pp. 198-211. In: Coal Conversion and the Environment: Chemical, Biomedical and Ecological Considerations, D. D. Mahlum, R. H. Gray, and W. D. Felix (eds), 20th Hanford Life Sciences Symposium, October 19-23, 1980, Richland, WA. CONF-801039, NTIS, Springfield, VA.

Becker, C. D. and D. W. Crass. 1982. Examination of procedures for acute toxicity tests with the fathead minnow and coal synfuel blends. Arch. Environ. Contam. Toxicol. 11: 33-40.

Becker, C. D., W. E. Fallon, D. W. Crass, and A. J. Scott. Acute toxicity of water-soluble fractions derived from a coal liquid (SRC-II) to three aquatic organisms. Water, Air, Soil Pollut. (in press).

Becker, C. D., W. C. Woodfield, and J. A. Strand. 1978. Solvent Refined Coal Studies: Effects and Characterization of Treated Solvent Refined Coal Effluent, PNL-26D8, Pacific Northwest Laboratory, Richland, WA. NTIS, Springfield, VA, $29 \mathrm{p}$.

BPNL. 1980. Synfue1s, pp. 1-5. In: Interagency/Contract Research, Ecological Sciences Department, Battelle, Pacific Northwest Laboratories, Richland, WA.

Brown, R. and A. Witter (eds.). 1979. Health and Environmental Effects of Coal Gasification and Liquefaction Technologies, D0E/HEW/EPA-03, Interagency Report. MITRE Corp., McLean, VA.

Buchanan, M. V., C.-H. Ho, B. R. Clark, and M. R. Guerin. 1981. Chemical characterization of mutagenic nitrogen-containing polycyclic aromatic hydrocarbons in fossil fuels, pp. 133-144. In: Polynuclear Aromatic Hydrocarbons: Chemical Analysis and Biological Fate, M. Cooke and A. J. Dennis (eds.), Fifth International Symposium, October 28-30, 1980, Columbus, $\mathrm{OH}$. Battelle Press, Columbus, $\mathrm{OH}$.

Calkins, W. H., J. F. Deye, R. W. Hartgrove, C. F. King, and D. F. Krahn. 1982. Synthetic crude oils from coal: Mutagenicity and tumor-initiation screening tests, pp. 462-470. In: Coal Conversion and the Environment: Chemical, Biomedical and Ecological Considerations, D. D. Mahlum, R. H. Gray, and W. D. Felix (eds), 20th Hanford Life Sciences Symposium, October 19-23, 1980, Richland, WA. CONF-801D39, NTIS, Springfield, VA.

Cline, J. F., W. H. Rickard, and M. E. Thiede. 1982. Growth of barley exposed to solvent-refined coal (SRC) materials added to soil, pp. 248-255. In: Coal Conversion and the Environment: Chemical, Biomedical and Ecological Consider 
ations, D. D. Mahlum, R. H. Gray, and W. D. Felix (eds.), 20th Annual Hanford Life Sciences Symposium, October 19-23, 1980, Richland, WA. CONF-801039, NTIS, Springfield, VA.

Coffin, D. L., M. R. Guerin, and W. H. Griest. 1979. The interagency program in health effects of synthetic fossil fuels technologies: 0peration of a materials repository, pp. 153-155. In: Proceedings of the Symposium on Potential Health and Environmental Effects of Synthetic Fossil Fuel Technologies. CONF-780903, NTIS, Springfield, VA.

Cowser, K. E. (ed.). 1980. Environmental and Health Program for an H-Coal Pilot Plant, Oak Ridge National Laboratory, Oak Ridge, TN, 160 p.

Cowser, K. E. (ed.). 1981. Life Sciences Synthetic Fuels Semiannual Progress Report for the Period Ending June 30, 1981, ORNL/TM-7926, 0ak Ridge National Laboratory, Oak Ridge, TN, $213 \mathrm{p}$.

Cowser, K. E. (ed.). 1982. Life Sciences Synthetic Fuels Semiannual Progress Report for the Period Ending Oecember 31, 1981, ORNL/TM-8229, Oak Ridge National Laboratory, Oak Ridge, TN, $93 \mathrm{p}$.

Cowser, K. E. (ed.). 1981. Quarterly Progress Report for the Period Ending June 30, 1980, ORNL/TM-7469, Oak Ridge National Laboratory, Oak Ridge, TN, 29 p.

Cushman, R. M. and M. I. McKamey. 1981. A Chironomus tentans bioassay for testing synthetic fuel products and effluents with data on acridine and quinoline. Bu11. Environ. Contam. Toxicol. 26: 601-605.

Dauble, D. O., W. E. Fallon, R. H. Gray, and R. M. Bean. 1982. Chronic toxicity of water-soluble fractions of fresh and water-leached solvent-refined coal-II (SRC-II) liquids to a freshwater benthic invertebrate, pp. 212-236. In: Coal Conversion and the Environment: Chemical, Biomedical and Ecological Considerations, D. D. Mahlum, R. H. Gray, and W. D. Felix (eds.), 20th Annual Hanford Life Sciences Symposium, October 19-23, 1980, Richland, WA. CONF801039, NTIS, Springfield, VA.

Dauble, D. D., W. E. Fallon, R. H. Gray, and R. M. Bean. Effects of coal liquid water-soluble fractions on growth and survival of four aquatic organisms. Arch. Environ. Contam. Toxicol. (in press).

Dauble, D. D., E. W. Lusty, W. E. Fallon, and R. H. Gray. 1981. Mixing and separation device for continuous flow bioassays with coal liquids. Bull. Environ. Contam. Toxicol. 26: 717-723.

Davis, K. R., T. W. Schultz, and J. N. Dumont. 1981. Toxic and teratogeriic effects of selected aromatic amines on embryos of the amphibian, Xenopus laevis. Arch. Environ. Contam. Toxicol. 10: 371-391.

DeGraeve, G. N., D. L. Geiger, J. G. Meyer, and H. L. Bergman. 1980. Acute and embryo-larval toxicity of phenolic compounds to aquatic biota. Arch. Environ. Contam. Toxicol. 9: 577-568. 
DOE. 1979a. Project Environmental Plan for the SRC-I Demonstration Plant, U.S. Department of Energy, Washington, DC, $11 \mathrm{p}$.

D0E. 1979b. Project Environmental Plan for the SRC-II Demonstration Plant, U.S. Department of Energy, Washington, DC, $11 \mathrm{p}$.

DOE. 1979c. Project Environmental Plan for the Exxon Donor Solvent (EDS) Pilot Plant, U.S. Department of Energy, Washington, DC, $11 \mathrm{p}$.

DOE. 1979d. Project Environmental Plan for the H-Coal Demonstration Plant, U.S. Department of Energy, Washington, DC, $9 \mathrm{p}$.

DOE. 1980. Environmental Development Plan for Coal Liquefaction, U.S. Department of Energy, Washington, DC, $9 \mathrm{p}$.

Dumont, J. N., T. W. Schultz, and R. D. Jones. 1979. Toxicity and teratogenicity of aromatic amines to Xenopus laevis. Bul1. Environ. Contam. Toxicol. 22: $159-166$.

Epler, J. L., R. J. M. Fry, F. W. Larimer, T. K. Rao, J. N. Dumont, T. W. Schultz, A. W. Hsie, H. Witschi, L. H. Smith, W. M. Haschek, and J. M. Holland. 1981. Health Effects Research in Direct Coal Liquefaction. Studies of $\mathrm{H}$-Coal Distillates: Phase I. PDU Samples - The Effects of Hydrotreatment, DRNL/TM-8071, Oak Ridge National Laboratory, Dak Ridge, TN, 53 p.

Epler, J. L., J. A. Young, A. A. Hardigree, T. K. Rao, M. R. Guerin, I. 8. Rubin, C.-H. Ho, and B. R. Clark. 1978. Analytical and biological analyses of test materials from synthetic fuel technologies. I. Mutagenicity of crude oils determined by the Salmonella typhimurium/microsomal activation system. Mutat. Res. 37: 365-276.

Exxon Research and Engineering Co. 1981. EDS Coal Liquefaction Process Development Phase V. EDS Product Quality, FE-2893-68, U.S. Department of Energy, Washington, $\mathrm{DC}, 370 \mathrm{p}$.

Felice, L. J. 1981. Determination of alkyl anilines and alkyl pyridines in solvent refined coal distillates and aqueous extracts by gas chromatography/ mass spectrometry. Anal. Chem. 54: 869-872.

Felice, L. J. and J. M. Zachara. The Terrestrial Fate of Coal-Liquid Constituents: Behavior of Alkyl Anilines in Soil, PNL-4222, Pacific Northwest Laboratory, Richland, WA. NTIS, Springfield, VA (in press).

Felix, W. D., D. D. Mahlum, W. C. Weimer, R. A. Pelroy, and B. W. Wilson. Chemical and biological characteristics of SRC-II products and by-products. In: Proceedings of the Symposium on Environmental Aspects of Fuel Conversion Technology, $v$, September 16-19, 1980, St. Louis, M0. U.S. Environmental Protection Agency, Washington, $O C$ (in press).

Flotard, R. D., J. R. Stetter, and V. C. Stamoudis. 1982. Workplace air sampling at coal conversion facilities, pp. 159-172. In: Coal Conversion and the Environment: Chemical, Biomedical, and Ecological Considerations, D. D. Mahlum, R. H. Gray, and W. D. Felix (eds.), 20th Annual Hanford Life Sciences Symposium, October 19-23, 1980, Richland, WA. CONF-801039, NTIS, Springfield, VA. 
Fruchter, J. 5., J. C. Laul, M. R. Petersen, P. W. Ryan, and M. E. Turner. 1978. High-precision trace element and organic constitutent analys is of oil shale and solvent refined coal materials, pp. 255-281. In: Analytical Chemistry of Liquid Fuel Sources, P. C. Uden, 5. Siggia, and H. B. Jensen (eds.), American Chemical Society, Washington, OC.

Fruchter, J. S. and M. R. Petersen. 1979. Environmental characterization of products and effluents from coal conversion processes, pp. 247-275. In: Analytical Methods for Coal and Coal Products, Vol. III, Academic Press, New York.

Gammage, R. B., T. Vo-Dinh, A. R. Hawthorne, J. H. Thorngate, and W. W. Parkinson. 1978. A new generation of monitors for polynuclear aromatic hydrocarbons from synthetic fuel production, pp. 155-174. In: Carcinogenesis, A Comprehensive Survey, Volume 3, Polynuclear Aromatic Hydrocarbons, P. W. Jone:s and R. I. Freudenthal (eds.), Second International Symposium on Analysis, Chemistry, and 8iology, September 1977, Columbus, OH. Raven Press, New York.

Gehrs, C. W. 1980. Synthetic fuels program, pp. 67-74. In: Oak Ridge National Laboratory Environmental Services Division Annual Progress Report for the Period Ending September 30, 1979, ORNL-5620, Oak Ridge National Laboratory, Oak Ridge, TN.

Gehrs, C. W. 1981. Advanced fossi1 energy program, pp. 1-21. In: Oak Ridge National Laboratory Environmental Services Division Annual Progress Report for the Period Ending September 30, 1980, ORNL-5700, Oak Ridge National Labora*tory, Dak Ridge, TN.

Gehrs, C. W., 0. S. Shriner, S. E. Herbes, E. J. Salmon, and H. Perry. 1981. Environmental, health and safety implications of increased coal utilization, pp. 2159-2223. In: Chemistry of Coal Utilization, M. A. Elliott (ed.), Second Supplementary Volume. John Wiley \& Sons, Inc., New York.

Giddings, J. M. 1980. Four-hour algal bioassays for assessing the toxicity of coal-derived materials, pp. 104-116. In: Proceedings of the 2nd Symposium on Process Measurements for Environmental Assessment, Arthur D. Little, Inc., Cambridge, MA.

Giddings, J. M. 1981. Toxicity of shale oil to freshwater algae: Comparisons with petroleum and coal-derived oils, pp. 189-199. In: Health Effects Investigation of Shale $0 i l$ Development, W. H. Griest et al. (eds.), June $23-$ 24, 1980, Gatlinburg, TN. Ann Arbor Science Publishers, Ann Arbor, MI.

Giddings, J. M. Effects of the water-soluble fraction of a coal-derived oil on pond microcosms. Arch. Environ. Contam. Toxicol. (in press).

Giddings, J. M., B. R. Parkhurst, C. W. Gehrs, and R. E. Millemann. 1980. Toxicity of a coal 1 iquefaction product to aquatic organisms. 8ull. Environ. Contam. Toxicol. 25: 1-6.

Giddings, J. M. and J. N. Washington. 1981. Coal liquefaction products, shale oil, and petroleum: Acute toxicity to freshwater algae. Environ. Sci. Technol. 15: $106-108$. 
Gray, R. H. and H. Drucker. 1981. Assessing health and environmental effects of a developing fuel technology, pp. 499-507. In: Beyond the Energy Crisis: Opportunity and Challenge, Volume II, R. A. Fazzolare and C. B. Smith (eds.), Third International Conference on Energy Use Management, October 26-30, 1981, Berlin (West), Germany. Pergamon Press, 0xford, England.

Gray, R. H., R. W. Hanf, D. D. Dauble, and J. R. Skalski. 1982. Chronic effects of a coal liquid on a freshwater alga Selenastrum capricornutum. Environ. Sci. Technol. 16(4): 225-229.

Gray, R. H. and J. B. States. 1979. Evaluating environmental effects of coal liquefaction materials on aquatic systems. In: Proceedings, 30th Alaska Science Conference, September 19-21, 1979, AAAS, Alaska Div. and ACS, Alaska Section, Fairbanks, AK.

Griest, W. H., B. A. Tomkins, J. L. Epler, and T. K. Rao. 1979. Characterization of multialkylated polycyclic aromatic hydrocarbons in energy-related materials, pp. 395-409. In: Polynuclear Aromatic Hydrocarbons, P. W. Jones and P. Leber (eds.), Third International Symposium on Chemistry and Biology-Carcinogenesis and Mutagenesis, October 1978, Columbus, OH. Ann Arbor Science Publishers, Ann Arbor, MI.

Guerin, M. R. 1978. Energy sources of polycyclic aromatic hydrocarbons, pp. 3-42. In: Polycylic Hydrocarbons and Cancer, H. V. Gelboin and P. O. P. Tso (eds.), Academic Press, New York.

Guerin, M. R., B. R. Clark, C. -H. Ho, J. L. Epler, and T. K. Rao. 1978. Shortterm bioassay of complex organic mixtures. Part I. Chemistry, pp. 247-268. In: Application of Short-Term Bioassays in the Fractionation and Analys is of Complex Environmental Mixtures, EPA Report No. 600/9-78-027, U.S. Environmenta? Protection Agency, Washington, DC.

Guerin, M. R., J. L. Epler, W. H. Griest, B. R. Clark, and T. K. Rao. 1978. Polycyclic aromatic hydrocarbons from fossil fuel conversion processes, pp. 21-33. In: Carcinogenesis, A Comprehensive Survey, Volume 3, Polynuclear Aromatic Hydrocarbons, P. W. Jones and R. I. Freudenthal (eds.), Second International Symposium on Analysis, Chemistry and Biology, September 1977, Columbus, OH. Raven Press, New York.

Guerin, M. R., A. A. Hardigree, and J. L. Epler. 1976. Fractionation of synthetic crude oils from coal for biological testing. Environ. Res. 12: 358-365.

Guerin, M. R., C.-H. Ho, T. K. Rao, B. R. Clark, and J. L. Epler. 1980. Polycyclic aromatic primary amines as determinant chemical mutagens in petroleum substitutes. Environ. Res. 23: 42-53.

Guerin, M. R., C.-H. Ho, T. K. Rao, B. R. Clark, and J. L. Epler. 1980. Separation and identification of mutagenic constituents of petroleum substitutes. Int. J. Environ. Anal. Chem. B: 217-225.

Guerin, M. R., I. B. Rubin, T. K. Rao, B. R. Clark, and J. L. Epler. 1981. 0istribution of mutagenic activity in petroleum and petroleum substitutes. Fuel 60: 282-288. 
Hawthorne, A. R. 1980. DUVAS: A real-time aromatic vapor monitor for ccal conversion facilities. Am. Ind. Hyg. Assoc. J. 41: 915-921.

Henry, S. A. 1937. The study of fatal cases of cancer of the scrotum from 1911 to 1935 in relation to occupation with special reference to chimney sweeping and cotton mule spinning. Am. J. Cancer 31: 28-57.

Herbes, S. E. 1981. Rates of microbial transformation of polycyclic aromatic hydrocarbons in water and sediments in the vicinity of a coal-coking wastewater discharge. Appl. Environ. Microbiol. 41: 20-28.

Herbes, S. E., G. R. Southworth, D. L. Shaeffer, W. H. Griest, and M. P. Maskarinec. 1980. Critical pathways of polycyclic aromatic hydrocarbons in aquatic enviroments, pp. 113-128. In: The Scientific Basis for Toxicity Assessment, H. R. Witschi (ed.), Elsevier/North Holland, New York.

Ho, C.-H., M. V. Buchanan, B. R. Clark, and M. R. Guerin. 1982. Chemical characterization of synfuel neutral fractions, pp. 34-53. In: Coal Conversion and the Environment: Chemical, Biomedical, and Ecological Considerations, $D$. D. Mahlum, R. H. Gray, and W. D. Felix (eds.), 20 th Annual Hanford Life Sciences Symposium, October 19-23, 1980, Richland, WA. CDNF-801039, NTIS, Springfield, VA.

Ho, C. -H., B. R. Clark, M. R. Guerin, B. D. Barkenbus, T. K. Rao, and J. L. Epler. 1981. Analytical and biological analyses of test materials from the synthetic fuel technologies. IV. Studies of chemical structure-Mutagenic activity relationships of aromatic nitrogen compounds relative to synfuels. Mutat. Res. 85: 335-345.

Ho, C. -H., C. Y. Ma, B. R. Clark, M. R. Guerin, T. K. Rao, and J. L. Epler. 1980. Separation of neutral nitrogen compounds from synthetic crude oils for biological testing. Environ. Res. 22: 412-422.

Holland, J. M., B. M. Eisenhower, L. C. Gipson, L. H. Smith, T. J. Stephens, and $M$. S. Whitaker. 1980. Assessment of the carcinogenic risk from energy related organics. In: Proceedings of the 4th Interagency Energy/Environment R \& D Conference, Washington, DC.

Holland, J. M., R. 0. Rahn, L. H. Smith, B. R. Clark, S. S. Chang, and T. J. Stephens. 1979. Skin carcinogenicity of synthetic and natural petroleums. J. Occup. Med. 21: 614-619.

Holland, J. M., M. S. Whitaker, and J. R. Wesley. 1979. Correlation of fluorescence intensity and carcinogenic potency of synthetic and natural petroleums in mouse skin. Am. Ind. Hyg. Assoc. J. 40: 496-502.

Holland, J. M., D. A. Wolf, and B. R. Clark. 1981. Relative potency estimation for synthetic petroleum skin carcinogens. Environ. Health Perspect. 38: $149-155$.

Holmes, S. A., P. W. Woodward, G. P. Strum, Jr., J. W. Vogh, and J. E. Dooley. 1976. Characterization of Coal Liquids Derived from the H-Coal Process, BERC/ RI-76/10, Bartlesville Energy Research Center, Bartlesville, OK. 
Hueper, W. C. 1956a. Experimental carcinogenic studies on hydrogenated coal oils: I. Bergius oils. Ind. Med. Surg. 25: 51-55.

Hueper, W. C. 1956b. Experimental carcinogenic studies on hydrogenated oils: II. Fisher-Tropsch oils. Ind. Med. Surg. 25: 459-462.

Jones, A. R., M. R. Guerin, and B. R. Clark. 1977. Preparative scale liquid chromatographic fractionation of crude oils derived from coal and shale. Anal. Chem. 49: 1766-1770.

Kelman, B. J. and D. L. Springer. 1982. Fetal exposure to benzo[a]pyrene across the hemochorial placenta, pp. 387-397. In: Coal Conversion and the Environment: Chemical, Biomedical and Ecological Considerations, D. D. Mahlum, R. H. Gray, and W. D. Felix (eds.), 20th Annual Hanford Life Sciences Symposium, October 19-23, 1980, Richland, WA. CONF-801039, NTIS, Springfield, VA.

Kelman, B. J. and D. L. Springer. 1982. Movement of benzo[a]pyrene across the hemochorial placenta of the guinea pig. Proc. Soc. Exp. Biol. Med. 169: 58-62.

Kimball, R. F. and N. B. Munro. 1981. A Critical Review of the Mutagenic and other Genotoxic Effects of Direct Coal Liquefaction, ORNL-5721, Oak Ridge $\mathrm{Na}^{-}$ tional Laboratory, Oak Ridge, TN, $199 \mathrm{p}$.

Lane, D. A., T. Sakima, and E. S. K. Quan. 1980. Real-time analysis of gas phase polycyclic aromatic, pp. 199-214. In: Polynuclear Aromatic Hydrocarbons: Chemistry and Biological Effects, A. Bjorseth and A. J. Dennis (eds.), Fourth International Symposium, October 1979, Columbus, OH. Battelle Press, Columbus, $\mathrm{OH}$.

LaRiviere, M. G., A. J. Scott, W. G. Woodfield, and C. E. Cushing. 1978. A Bibliography on Cycling of Trace Metals in Freshwater Ecosystems, PNL-2706, Pacific Northwest Laboratory, Richland, WA. NTIS, Springfield, VA, 11 p.

Later, D. W., M. L. Lee, K. D. Bartle, R. C. Kong, and D. L. Vassilaros. 1981. Chemical class separation and characterization of organic compounds in synthetic fuels. Anal. Chem. 53: 1612-1620.

Later, D. W. , M. L. Lee, and B. W. Wilson. 1982. Selective detection of amino polycyclic aromatic compounds in solvent refined coal. Ana1. Chem. 54: 117-123.

Leggett, N., D. Britt, T. Williams, M. Subramanian, and M. Parish. Preliminary Assessment of Spills from the Transportation and Storage of Coal-Derived Synthetic Fuel, ORNL/TM-7606, 0ak Ridge National Laboratory, Oak Ridge, TN (in press).

Leversee, G. J., J. P. Giesy, Jr., P. F. Landrum, S. Barte11, S. Gerould, M. Bruno, A. Spacie, J. Bowling, J. Haddock, and T. Fannin. 1981. Disposition of benzo[a]pyrene in aquatic systems components: Periphyton, chirononids, Daphnia fish, pp. 357-366. In: Polynuclear Aromatic Hydrocarbons: Chemical Analysis and Biological Fate, M. Cooke and A. J. Dennis (eds.), Fifth International Symposium, October 1980, Columbus, OH. Battelie Press, Columbus, OH. 
Leversee, G. J., J. P. Giesy, Jr., P. F. Landrum, S. Gerould, J. W. Bowling, T. E. Fannin, J. D. Haddock, and S. M. Barte11. Kinetics and biotransformation of benzo[a]pyrene in Chironomus riparius. Arch. Environ. Contam. Toxicol. (in press).

Loscutoff, S. M., B. W. Killand, D. L. Springer, and D. D. Mahlum. 1982. Histamine aerosol challenge tests in guinea pigs exposed to a high-boiling-point coal liquid, pp. 433-444. In: Coal Conversion and the Environment: Chemical, Biomedical and Ecological Considerations, D. D. Mahlum, R. H. Gray, and W. D. Felix (eds.), 20th Annual Hanford Life Sciences Symposium, October 19-23, 1980, Richland, WA. CONF-801039, NTIS, Springfield, VA.

Mahlum, O. D. (ed.). 1981. Chemical, Biomedical and Ecological Studies of SRC-I Materials from the Ft. Lewis Pilot Plant: A Status Report, PNL-3474, Pacific Northwest Laboratory, Richland, WA. NTIS, Springfield, VA, 62 p.

Mahlum, D. D., R. H. Gray, and W. D. Felix (eds.). 1982. Coal Conversion and the Environment: Chemical, 8iomedical and Ecological Considerations, 20th Annual Hanford Life Sciences Symposium, October 19-23, 1980, Richland, WA. CONF-801039, NTIS, Springfie1d, VA, $607 \mathrm{p}$.

Mahlum, D. D., R. A. Pelroy, H. Drucker, B. W. Wilson, M. J. Massey, and D. K. Schmalzer. 1981. Toxicology studies of SRC materials, pp. 634-648. In: Proceedings, Second U.S. DOE Environmental Control Symposium, March 1980, Reston, VA. CONF-800334/1, NTIS, Springfie1d, VA.

Mazumdar, 5., C. Redmond, W. Sollecito, and N. Sussman. 1975. An epidemi-ological study of exposure to coal tar pitch volatiles among coke oven workers. J. Air Pollut. Cont. Assoc. 25: 382-389.

McLaughlin, S., B. Taylor, and G. E. Taylor, Jr. 1980. Relative humidity: Important modifier of pollutant uptake in plants. Science 211: 167-168.

Mellinger, P. J., B. W. Wilson, D. D. Mahlum, L. E. Sever, and A. R. 01 sen. Health and Environmental Effects Document for Direct Coal Liquefaction - 1981, PNL-4230, Pacific Northwest Laboratory, Richland, WA. NTIS, Springfield, VA (in press).

Mercer, B. W., W. Wakamiya, S. E. Petty, J. A. Strand, and D. D. Mahlum. Assessment of synfuel spill clean-up options. In: Proceedings of the DOE Workshop on Processing Needs and Methodology for Waste Water from the Conversion of Coal, 011 Shale, and Biomass to Synfuels, July 23, 1981, Washington, DC. NTIS, Springfield, VA (in press).

Meyer, H. R., E. D. Copenhauer, and D. C. Parzyck. Hea1th and Environmental Effects Document on Coal Liquefaction - 1981, 0ak Ridge National Laboratory, 0ak Ridge, TN (in press).

Milleman, R. E., B. J. Parkhurst, and N. T. Edwards. 1982. Toxicity to Daphnia magna and terrestrial plants of solid-waste leachates from coal conversion processes, pp. 237-255. In: Coal Conversion and the Environment: Chemical, Biomedical and Ecological Considerations, D. D. Mahlum, R. H. Gray, and W. D. Felix (eds.), 20th Annual Hanford Life Sciences Symposium, October 19-23, 1980 , Richland, HA. CONF-801039, NTIS, Springfield, VA. 
Moxley, C. R. and D. K. Schmalzer. 1979. Environmental assessment of SRC-II: An update, pp. 357-382. In: Proceedings of the Symposium on Environmental Aspects of Coal Conversion Technology: IV, EPA-600/7-79-217, Hollywood, FL. U.S. Environmental Protection Agency, Washington, DC.

Parkhurst, B. R., A. S. Bradshaw, J. C. Forte, and G. P. Wright. 1981. The chronic toxicity to Daphnia magna of acridine, a representative azaarene present in synthetic fossil fuel products and wastewaters. Environ. Pollut. 24: $21-30$.

Parkhurst, B. R., R. E. Mitlemann, and R. H. Strand. Toxicities of solid wastes, wastewaters, and products from synthetic fuel processes to aquatic organisms. Environ. Sci. Technol. (in press).

Paudler, W. W. and M. Cheplen. 1979. Nitrogen bases in solvent refined coal. Fuel 58: 775-778.

Pelroy, R. A. (ed.). 1981. The Mutagenic and Chemical Properties of SRC-I Materials: A Status Report, PNL-3604, Pacific Northwest Laboratory, RichTand, WA. NTIS, Springfield, VA, $20 \mathrm{p}$.

Pelroy, R. A. and A. J. Gandolfi. 1980. Use of a mixed-function amine oxidase for metabolic activation in the Ames/Salmonella assay system. Mutat. Res. 72: 329-334.

Pelroy, R. A. and M. R. Petersen. 1981. Mutagenic characterization of synthetic fuel materials by the Ames/Salmonella assay system. Mutat. Res. 90: 309-320.

Pelroy, R. A., D. S. Sklarew, and S. P. Downey. 1981. Comparison of the mutagenicity of fossil fuels. Mutat. Res. 90: 232-245.

Pelroy, R. A. and D. L. Stewart. 1981. The effects of nitrous acid on the mutagenicity of two coal 7 iquids and their genetically active chemical fractions. Mutat. Res. 90: 297-30B.

Pelroy, R. A. and B. W. Wilson (eds.). 1981. Fractional Distillation as a Strategy for Reducing the Genotoxic Potential of SRC-II Coal Liquids: A Status Report, PNL-3787, Pacific Northwest Laboratory, Richland, WA. NTIS, Springfield, VA, $62 \mathrm{p}$.

Pelroy, R. A. and B. W. Wilson. 1981. Relative concentrations of polyaromatic primary amines and azaarenes in mutagenically active nitrogen fractions from a coal liquid. Mutat. Res. 90: 321-335.

Petty, S. E., W. Wakamiya, C. J. English, J. A. Strand, and D. D. Mahlum. 19B2. Assessment of Synfuel Spill Cleanup Options, PNL-4244, Pacific Northwest Laboratory, Richland, WA. NTIS, Springfield, VA.

PNL. 1977. Coal technology, pp. 1.30-1.34. In: Pacific Northwest Laboratory Annual Report for 1976 to the ERDA Assistant Administrator for Environment and Safety, Part 2, Ecological Sciences, PNL-2100. NTIS, Springfield, VA. 
PNL. 1978. Coal conversion, pp. 1.13-1.17. In: Pacific Northwest Laboratory Annual Report for 1977 to the DOE Assistant Secretary for Environment, Part 2, Ecological Sciences, PNL-2500. NTIS, Springfield, VA.

PNL. 1979. Appendix to Biomedical Studies on Solvent Refined Coal (SRC-II) Liquefaction Materials: A Status Report, PNL-3189, Pacific Northwest Laboratory. NTIS, Springfield, VA.

PNL. 1979. Biomedical Studies on Solvent Refined Coal (SRC-II) Liquefaction Materials: A Status Report, PNL-3189, Pacific Northwest Laboratory. NTIS, Springfield, VA, $54 \mathrm{p}$.

PNL. 1979. Solvent refined coal biostudies, pp. 1.35-1.47. In: Pacific Northwest Laboratory Annual Report for 1978 to the DOE Assistant Secretary for Environment, Part 1, Biomedical Sciences, PNL-2850. NTIS, Springfield, VA.

PNL. 1979. Synfuels, pp. 3.3-3.7. In: Pacific Northwest Laboratory Annual Report for 1978 to the $00 E$ Ass istant Secretary for Environment, Part 2, EcoTogical Sciences, PNL-2850. NTIS, Springfield, VA.

PNL. 1980. Solvent refined coal biostudies, pp. 27-67. In: Pacific Northwest Laboratory Annual Report for 1979 to the DOE Assistant Secretary for Environment, Part 1, Biomedical Sciences, PNL-3300. NTIS, Springfield, VA.

PNL. 1980. Solvent Refined Coal-II (SRC-II) Detailed Environmental Plan, PNL-3517, Pacific Northwest Laboratory. NTIS, Springfie1d, VA, $122 \mathrm{p}$.

PNL. 1980. Solvent refined coal effluent/product characterization, pp. 5-10. In: Pacific Northwest Laboratory Annual Report for 1979 to the DOE Assistant Secretary for Environment, Part 4, Physical Sciences, PNL-3300. NTIS, Springfield, VA.

PNL. 1980. Synfue1s, pp. 43-54. In: Pacific Northwest Laboratory Annual Report for 1979 to the DOE Assistant Secretary for the Environment, Part 2, Ecological Sciences, PNL-3300. NTIS, Springfield, VA.

PNL. 1981. Characterization of materials from the solvent refined coal processes, pp. 6-7. In: Pacific Northwest Laboratory Annual Report for 1980 to the DOE Assistant Secretary for Environment, Part 4, Physical Sciences, PN_37D0. NTIS, Springfield, VA.

PNL. 1981. Coal, pp. 29-31. In: Pacific Northwest Laboratory Annual Report for 1980 to the DOE Assistant Secretary for Environment, Part 1, Biomedica 7 Sciences, PNL-3700. NTIS, Springfield, VA.

PNL. 1981. Synfuels, pp. 49-61. In: Pacific Northwest Laboratory Annual Report for 1980 to the DOE Assistant Secretary for Environment, Part 2, Ecological Sciences, PNL-3700. NTIS, Springfield, VA.

PNL. 1981. Volume I, Solvent Refined Coal-I (SRC-I) Joint Environmental Plan: Health and Ecological Effects (Draft). Pacific Northwest Laboratory, Richland, WA, $120 \mathrm{p}$. 
PNL. 1982. Chemical characterization of materials from coal liquefaction processes, pp. 6-9. In: Pacific Northwest Laboratory Annual Report for 1981 to the DOE Office of Energy Research, Part 4, Physical Sciences, PNL-4l00. NTIS, Springfield, VA.

PNL. 1982. Coal, pp. 3-24. In: Pacific Northwest Laboratory Annual Report for 1981 to the DOE Office of Energy Research, Part 1, Biomedical Sciences, PNL-4100. NTIS, Springfield, VA.

PNL. 1982. Synfue 1s, pp. 57-71. In: Pacific Northwest Laboratory Annual Report for 1981 to the DOE Office of Energy Research, Part 2, Ecological Sciences, PNL-4100. NTIS, Springfield, VA.

Poston, T. M. 1979. Effects of Phenol on ATPase Activities in Crude 0il Homogenates of Rainbow Trout (Salmo gairdneri Richardson), PNL-2697, Pacific Northwest Laboratory, Richland, WA. NTIS, Springfield, VA, 52 p.

Renne, R. A. and L. G. Smith. 1981. Carcinogenic effects of coal conversion materials, pp. 9-20. In: Proceedings of the Workshop on Industrial Hygiene and Occupational Medicine in Coal Conversion Products, November 6-7, 1980 , Washington, DC. CONF-801143, NTIS, Springfield, VA.

Renne, R. A., L. G. Smith, and D. D. Mahlum. 1982. Epidermal carcinogenicity of some crude fossil fuels in mice: A preliminary report, pp. 471-481. In: Coal Conversion and the Environment: Chemical, Biomedical and Ecological Considerations, D. D. Mahlum, R. H. Gray, and W. D. Felix (eds.), 2Dth Annual Hanford Life Sciences Symposium, October 19-23, 1980, Richland, WA. CONF801039 , NTIS, Springfield, VA.

Rickard, W. H., J. F. Cline, and R. G. Schreckhise. 1979. A Small WeighingLeaching Lysimeter for Biological Research, PNL-SA-7664, Pacific Northwest Laboratory, Richland, WA, $4 \mathrm{p}$.

Rubin, I. B., M. R. Guerin, A. A. Hardigree, and J. L. Epler. 1976. Fractionation of synthetic crude oils from coal for biological testing. Environ. Res. 12: 358-365.

Schneider, M. J., S. A. Barraclough, R. G. Genoway, and M. L. Wolford. 1980. Effects of phenol on predation of juvenile rainbow trout, Salmo gairdneri. Environ. Pollut. (Series A) 23: 121-130.

Schultz, T. W. 1982. Acute cytotoxicity of fossil energy-related comparative research materials. J. Environ. Sci. Health (Part A) 17: 153-167.

Schultz, T. W. M. Cajina-Quezada, and J. N. Dumont. 1980. Structure-toxicity relationships of selected nitrogenous heterocyclic compounds. Arch. Environ. Contam. Toxicol. 9: 591-598.

Schultz, T. W. and J. N. Dumont. 1978. Cytotoxicity of untreated coal Tiquefaction process water (and a comparison with gasification process water). Environ. Sci. Health A13(9): 641-651. 
Schultz, T. W., L. M. Kyte, and J. N. Dumont. 1978. Structure-toxicity correlations of organic contaminants in aqueous coal-conversion effluents. Arch. Environ. Contam. Toxicol. 7: 457-463.

Schultz, T. W., S. T. Perry, and J. N. Dumont. 1978. Reduced toxicity of an aqueous coal-conversion effluent following waste disposal treatment. Bull. Environ. Contam. Toxicol. 20: 633-639.

Sexton, R. J. 1960. The hazards to health in the hydrogenation of coal. IV. The central program and the clinical effects. Arch. Environ. Health 1: 208-231.

Shriner, D. S., S. 8. McLaughlin, and G. E. Taylor, Jr. 1981. Ecological implications of air pollutants from synthetic fuels processing, pp. 669-676. In: Beyond the Energy Crisis: Opportunity and Challenge, Volume II, R. A. Fazzolare and C. B. Smith (eds.), Third International Conference on Energy Use Management, October 26-30, 1981, Berlin (West), Germany. Pergamon Press, Oxford, England.

Skalski, J. R. 1981. Statistical inconsistencies in the use of no-observedeffect levels in toxicity testing, pp. 371-387. In: Aquatic Toxicology and Hazard Assessment: Fourth Conference, ASTM STP $737, \bar{D}$. R. Branson and $K . \bar{L}$. Dickson (eds.), American Society for Testing and Materials, Philadelphia, PA.

Southworth, G. R. 1979. The role of volatilization in removing polycyclic aromatic hydrocarbons from aquatic environments. 8u11. Environ. Contam. Toxicol. 21: 507-514.

Southworth, G. R., C. C. Keffer, and J. J. Beauchamp. 1980. Potential and realized bioconcentrations--A comparison of observed and predicted bioconcentration of azaarenes in the fathead minnow (Pimephales promelas). Environ. Sci. Technol. 14: 1529-1531.

Southworth, G. R., C. C. Keffer, and J. J. Beauchamp. 1981. The accumulation and disposition of benz[a]acridine in the fathead minnow Pimephales promelas. Arch. Environ. Contam. Toxicol. 10: 561-569.

Southworth, G. R., B. R. Parkhurst, and J. J. Beauchamp. 1979. Accumulation of acridine from water, food, and sediment by the fathead minnow Pimephales promelas. Water, Air, Soil Pollut. 12: 331-341.

Springer, D. L., D. W. Phelps, and R. E. Schirmer. 1981. Obtaining quantitative data for PNAs anticipated in solvent refined coal with capillary column gas chromatography using split and splitless injection. J. High Resol. Chromatog. Chromatog. Comm. 4: 638-641.

Springer, D. L., D. H. Willard, C. J. Gerdes, D. W. Phelps, and D. D. Mahlun. 1982. An inhalation exposure systen for high-boiling coal 1iquids, pp. 419432. In: Coal Conversion and the Environment: Chemical, Biomedical and Eco* logical Considerations, D. D. Mahlum, R. H. Gray, and W. D. Felix (eds.), 20 th Annuai Hanford Life Sciences Symposium, October 19-23, 1980, Richland, WA. CONF-801039, NTIS, Springfield, VA.

Springer, 0. L., D. H. Willard, and D. D. Mahlum. Generation and delivery of coal Tiquid aerosols for inhalation studies. Am. Ind. Hyg. Assoc. J. (in press). 
States, J. B., C. D. Becker, M. J. Schneider, and J. A. Strand. 1979. Response of aquatic biota to effluents from the Fort Lewis, Washington solvent refined coal pilot plant, pp. 212-220. In: Proceedings of the Symposium on Potential Heaith and Environmental Effects of Synthetic Fossil Fuel Technologies. CONF-780903, NTIS, Springfield, VA.

States, J. B., W. E. Fallon, S. A. Barraclough, D. D. Oauble, J. R. 5kalski, and R. M. Bean. 1982. Comparative toxicity to a freshwater invertebrate from water-soluble fractions of a coal liquid and two reference oils, pp. 223-236. In: Coal Conversion and the Environment: Chemical, Biomedical and Ecological Considerations, D. D. Mahlum, R. H. Gray, and W. D. Felix (eds.), 20th Annual Hanford Life Sciences Symposium, October 19-23, 1980, Richland, WA. CONF801039, NTIS, Springfield, VA.

States, J. B., W. F. Harris, P. T. Haug, G. Kingsburg, E. Preston, P. Risser, R. Scott, R. Smal1, D. Stevens, J. E. Taylor, and C. H. Connally. 1979. Needed research on the terrestrial effects of coal gasification and liquefaction technologies. In: Summary and Panel Reports for the Federal Interagency Committee on the Health and Environmental Effects of Energy Technologies, R. Brown and A. Whittier (eds.), MTR-79W00137, DOE/HEW/EPA-03. NTIS, Springfield, VA.

Strand, J. A. and B. E. Vaughan (eds.). 1981. Ecological Fate and Effects of Solvent Refined Coal (SRC) Materials: A 5tatus Report, PNL-3819, Pacific Northwest Laboratory, Richland, WA. NTIS, Springfield, VA, 181 pp.

Taylor, G. E., Jr., S. B. McLaughlin, and D. S. Shriner. Effective pollutant dose. In: Effects of Gaseous Air Pollution on Vegetation, M. H. Unsworth and D. P. Ormrod (eds.), Butterworth Press, New York (in press).

Tomkins, B. A., J. E. Caton, and W. H. Griest. 1981. Liquid chromatographic determination of benzo[a]pyrene in natural, synthetic, and refined crudes. Anal. Chem. 53: 1213-1217.

Tomkins, B. A. and C.-H. Ho. 1982. Determination of polycyclic aromatic amines in natural and synthetic crudes. Anal. Chem. 54: 91-96.

Tomkins, B. A., H. Kubota, W. H. Griest, J. E. Caton, B. R. Clark, and M. R. Guerin. 1980. Determination of benzo[a]pyrene in petroleum substitutes. Anal. Chem. 52: 1331-1334.

Toste, A. P., 0. 5. Sklarew, R. A. Pelroy, D. M. Shengold, S. P. Downey, and W. C. Weimer. 1982. Comparison of the chemical and mutagenic properties of a coal liquid and a shale oil, pp. 96-114. In: Coal Conversion and the Environment: Chemical, Biomedical and Ecological Considerations, D. D. Mahlum, R. H. Gray, and W. D. Felix (eds.), 20th Annual Hanford Life Sciences Symposium, October 19-23, 1980, Richland, WA. CONF-801039, NTIS, Springfield, VA.

Vo-Dinh, T. and R. B. Gammage. 1980. Room temperature phosphorimetry for the analys is of environmental samples, pp. 139-153. In: Polynuclear Aromatic Hydrocarbons: Chemistry and Biological Effects, A. Bjorseth and A. J. Dennis (eds.), Fourth International Symposium, October 1979, Columbus, OH. Battelle Press, Columbus, $\mathrm{OH}$. 
Vo-Dinh, T. and R. G. Gammage. 1981. The lightpipe liminoscope for monitoring occupational skin contamination. Am. Ind. Hyg. As50C. J. 42: 112-120.

Vo-Dinh, T., R. B. Gammage, and A. R. Hawthorne. 1979. Analys is of orgaric pollutants by synchronous luminescence spectrometry, p. 111-119. In: Polynuclear Aromatic Hydrocarbons, P. W. Jones and P. Leber (eds.), Third International Symposium on Chemistry and Biology--Carcinogenesis and Mutagenesis, October 1978, Columbus, OH. Ann Arbor Science Publishers, Ann Arbor, MI.

Vo-Dinh, T. and J. H. Hooyman. 1979. Selective heavy-atom perturbation for improved analysis of complex mixtures by RTP. Anal. Chem. 51: 1915.

Vo-Dinh, T. and P. R. Martinez. 1981. Direct determination of selected PNA in a coal liquefaction product by synchronous luminescence techniques. Anal. Chim. Acta 125: 13.

Walton, B. T. 1980. Influence of route of entry on toxicity of polycyclic aromatic hydrocarbons to Acheta domesticus. Bull. Environ. Contam. Toxicol. 25: $289-293$.

Walton, B. T. 1981. Chemical impurity produces extra compound eyes and heads in crickets. Science 212: 51-53.

Wei1, C. S. and N. I. Condra. 1960. The hazards to heatth in the hydrogenation of coal-II. Carcinogenic effect of materials on the skin of mice. Arch. Environ. Health 1: 187-193.

Weimer, W. C., B. W. Wilson, R. A. Pelroy, and J. C. Craun. 1980. Initial Chemical and Biological Characterization of Hydrotreated Solvent Refined Coal (SRC-II) Liquids: A Status Report, PNL-3464, Pacific Northwest Laboratory, Richland, WA. NTIS, Springfield, VA, $46 \mathrm{p}$.

White, C. M., F. K. Schweighardt, and J. L. Shuty. 1978. Combined gas chromatographic/mass spectrometric analysis of nitrogen bases in light oil from a coal liquefaction product. Fuel Proc. Technol. 1: 209-215.

Willey, C., R. A. Pelroy, D. S. Sklarew, and B. W. Wilson. Chemical analysis and in vitro mutagenicity testing of water soluble constituents from an SRC solid product. In: Extended Abstracts, Division of Environmental Chemistry, American Chemical Society Meeting, American Chemical Society, August 1981, New York, NY (in press).

Wilson, B. W., J. C. Craun, R. A. Pelroy, M. R. Petersen, and W. D. Felix. 1980. Strategies for characterizing the fate of bioactive materials during coal liquefaction product upgrading. In: Proceedings, Second U.S. Department of Energy Environmental Control Symposium, Volume 1 , Fossil Energy, CoNF$800334 / 1$, NTIS, Springfield, VA.

Wilson, B. W. and R. A. Pelroy. 1979. Mass spectral analysis of mutagenic:ally active subfractions of coal liquids. In: Proceedings, 27 th ASMS Meeting, 1979, Seattle, WA. American Society for Mass Spectrometry, Bethesda, MD.

Wilson, B. W. and R. A. Pelroy. 1981. Effects of catalytic hydrogenation on coal liquids which exhibit microbial mutagenic activity, pp. 87-100. In: Cur- 
rent Topics in Environmental and Toxicological Chemistry, Vol. 3, Mutagenicity Testing and Related Analytical Techniques, R. W. Frei and V. A. Th. Brinkman (eds.), Gordon and Breach Science Publishers, New York, NY.

Wilson, B. W., R. A. Pelroy, and J. T. Cresto. 1980. Identification of primary aromatic amines in mutagenically active subfractions from coal liquefaction materials. Mutat. Res. 79: 193-202.

Wilson, B. W., R. A. Pelroy, M. Lee, and D. Later. 1981. Strategies for the identification of genotoxic constituents in heavy-end coal liquids. In: Proceedings of the American Society for Mass Spectrometry Meeting, June 1981, Minneapolis, MN. American Society for Mass Spectrometry, Bethesda, MD.

Wilson, B. W., R. A. Pelroy, and D. D. Mahlum. Chemical Characterization and Genotoxic Potential Related to Boiling Point for Fractionally Distilled SRC-I Coal Liquids, PNL-4277, Pacific Northwest Laboratory, Richland, WA. NTIS, Springfield, VA (in press).

Wilson, B. W. M. R. Petersen, R. A. Pelroy, and J. T. Cresto. 1981. In vitro assay for mutagenic activity and gas chromatographic-mass spectral analysis of coal-liquefaction material and the products resulting from its hydrogenation. Fuel 60: 289-294.

Wilson, B. W., A. P. Toste, R. A. Pelroy, B. Vieux, and D. Wood. 1982. Accurate mass/metastable ion analysis of higher molecular weight nitrogen compounds in coal liquids, pp. 148-158. In: Coal Conversion and the Environment: ChemiCal, Biomedical and Ecological Considerations, D. D. Mahlum, R. H. Gray, and W. D. Felix (eds.), 20 th Annual Hanford Life Sciences Symposium, October 1923, 1980, Richland, WA. CONF-801039, NTIS, Springfield, VA.

Woodbridge, D. D., J. I. Kim, and D. M. Hanson. 1982. Chemical and biological characteristics of waste streams of the SRC-II pilot plant, Pp. 128-147. In: In: Coal Conversion and the Environment: Chemical, Biomedical and Ecological Considerations, D. D. Mahlum, R. H. Gray, and W. D. Felix (eds.), 20th Annual Hanford Life Sciences Symposium, October 19-23, 1980, Richland, WA. CONF-801039, NTIS, Springfield, VA.

Updated - 07/08/82 

DOE/NBM-1016

PNL-4176

UC- $11,20 \mathrm{e}, 41,59,90 \mathrm{~d}$

\section{DISTRIBUTION LIST}

A. A. Churm

DOE Patent Division

9800 South Cass Avenue

Argonne, IL 60439

DOE Technical Information

Center (27)

E. L. Alpen

Lawrence Berkeley Laboratory

University of California

Building 90, Room 2056

No. 1 Cyclotron Road

Berkeley, CA 94720

L. D. Attaway

1005 A Steet

Suite 405

San Rafael, CA 94901

N. F. Barr

ER-73, GTN

U.S. Department of Energy

Washington, DC 20545

J. Batchelor

FE-43, GTN

U.S. Department of Energy

washington, DC 20545

D. L. Bauer

Acting Assistant Secretary

for Fossil Energy

FE-1, FORSTL

U.S. Department of Energy

Washington, DC 20585

H. L. Bergman

University of Wyoming

Laramie, WY 82071
C. Berlin

Health Environmental

Review Division

U.S. Environmental

Protection Agency

Washington, DC 20460

R. W. Biles

Exxon Corporation

Research and Environmental

Health Division

Medical Department

P. 0. Box 235

East Millstone, NJ 08873

J. R. Blair

ER-73, GTN

U.S. Department of Energy

Washington, DC 20545

V. P. Bond

Brookhaven National Laboratory

Upton, Long Island, NY 11973

J. E. Bratina, Jr.

Environmental Research and

Technology, Inc.

601 Grant Street

Porter Building, 10th Floor

Pittsburgh, PA 15219

P. E. Brubaker

Exxon Corporation

Research and Environmental

Hea]th Division

Medical Department

P. 0. Box 235

East Millstone, NJ 08873

P. Buhl

FE-43, GTN

U.S. Department of Energy

Washington, DC 20545 
F. P. Burke

Conoco Coal Development Co.

4000 Brownsville Road

Library, PA 15129

R. Burnette

Kentucky Dept. of Natural Resources and Environmental Protection

Frankfort, KY 40601

C. E. Carter

Scientific Director

National Institute of Environmental Health Sciences

P. 0. Box 12233

Research Triangle Park, NC 277D9

M. Chartock

Science \& Public Policy Program

Norman, OK 73019

C. T. Chen

OSHA

U.S. Department of Labor

20D Constitution Avenue, NW

Washington, DC 20210

P. Cho

ER-73, GTN

U.S. Department of Energy

Washington, DC 20545

A. V. Colucci

A. V. Colucci \& Associates, Inc.

15305 Calle Enrique, Suite D

Morgan Hill, CA 95037

K. E. Cowser (15)

Oak Ridge National Laboratory

P. 0 . Box $X$

0ak Ridge, TN 37830

G. Day

Kentucky Division of Air

Pollution Control

18 Riley Rd.

Frankfort, KY 40601

D. Denny

Environmental Research and

Technology, Inc.

601 Grant Street

Porter Building, 10th Floor

Pittsburgh, PA 15219
Department of Library and

Archives (2)

James Nelson, Librarian

Box 537, Berry Hill

Frankfort, KY 40602

DoE Public Document Room (2)

Attn: Mr. R. A. Evans

Room G-298, Federal Building

P. 0. Box E

Oak Ridge, TN 37830

DOE Public Reading Room, FDI (2)

Room IE-180, Forrestal Building

1000 Independence Avenue, SW

Washington, DC 20585

DOE Technical Information Center (2)

Customer Services 8ranch

P. 0 . Box 62

Oak Ridge, TN 37830

DOE Public Document Room (2)

Room G208

Oak Ridge Federal Building

Oak Ridge, TN 37830

DOE Public Reading Room (2)

Room GA- 142

Forrestal Building

1000 Independence Avenue, SW

Washington, DC 20585

B. 2. Drozdowicz

International Coal Refining Co.

P. 0. Box 2752

Allentown, PA 18001

C. Orummond

Pittsburgh Energy Technology Center

P. 0. Box 10940

Pittsburgh, PA 15236

A. P. Duhamel (30)

ER-74, GTN

U.S. Department of Energy

Washington, DC 20545

H. E. Dunn, Ph. D.

Indiana State University

Evansville

8600 University Boulevard

Evansville, IN 47702 
L. Eaker

Office of Senator Percy

1200 Dirksen Building

Washington, DC 20515

C. W. Edington, Associate Director

Office of Health and Environmental Research

ER-70, GTN

U.S. Department of Energy

Washington, DC 20545

H. Enoch

Kentucky Department of Energy

P. 0. Box 11888

Lexington, KY 40578

J. L. Epler

Oak Ridge National Laboratory

P. 0. Box $X$

Oak Ridge, TN 37830

Evansville \& Vanderburgh

County Public Library (2)

Attn: Ann Pearson

22 Southeast 5 th Street

Evansville, IN 47708

W. Fernald

FE-44, GTN

U.S. Department of Energy

Washington, DC 20545

J. P. Fillo

Environmental Research and

Technology, Inc.

601 Grant Street

Porter Building, 10th Floor

Pittsburgh, PA 15219

C. H. Fisher

FE-43, GTN

U.S. Department of Energy

Washington, DC 20545

S. Foster

Energy and Environmental

Analys is, Inc.

1111 North 19th Street

Arlington, VA 22209
Larry Fradkin

Argonne National Laboratory

Building 12

Argonne, IL 60439

R. E. Franklin

ER-75, GTN

U.S. Department of Energy

Washington, DC 20545

R. J. Fry

Oak Ridge National Laboratory

P. 0. Box $X$

Oak Ridge, TN 37830

K. Frye

FE-40, GTN

U.S. Department of Energy

Washington, DC 20545

C. W. Gehrs

Oak Ridge National Laboratory

P. 0. Box $X$

Oak Ridge, TN 37830

H. Gerstenkorn

Ruhrkohle 0el und Gas GMBH

Gleiwitzer Platz 3

4250 Bottropp

FEDERAL REPUBLIC OF GERMANY

J. M. Giddings

Oak Ridge National Laboratory

P. 0. Box $X$

Oak Ridge, TN 37830

L. Goldberg

Chemical Industrial

Institute of Toxicology

2109 Nancy Ann Drive

Raleigh, NC 27607

G. Goldstein

ER-74, GTN

U.S. Department of Energy

Washington, OC 20545

J. Gray

Ashland Synthetic Fuels, Inc.

P. 0. Box 391

Ashland, KY 41301 
M. D. Gray

NCB (Coal Products) Ltd.

Coal House, Lyon Rd., Harrow

HAI 2EX ENGLAND

A. R. Griesemer

Oak Ridge National Laboratory

P. 0 . Box $X$

Dak Ridge, TN 37830

M. Guerin

Oak Ridge National Laboratory

P. 0. Box $X$

Oak Ridge, TN 37830

R. M. Hamilton

FE-43, GTN

U.S. Department of Energy

Washington, DC 20545

\author{
A. Hartstein \\ FE-43, GTN \\ U.S. Department of Energy \\ Washington, DC 20545 \\ L. Headley \\ Morgantown Energy Technology Center \\ Morgantown, WV 26505
}

G. E. Hedstrom

FE-44, GTN

U.S. Department of Energy

Washington, DC 20545

B. Henschel (2)

Industrial Environmental Research Laboratory

MD-61, U.S. EPA

Research Triangle Park, NC 27711

J. $\mathrm{Hill}$

Ashland Synthetic Fuels, Inc.

P. 0. Box 39l

Ashland, KY 41101

R. $\mathrm{Hill}$

Ashland Synthetic Fuels, Inc.

P. 0. Box 39 ?

Ashland, KY 41101

C. H. Hobbs

Lovelace Inhalation Toxicology

Research Institute

P. 0. Box 5890

Albuquerque, NM 87115
J. M. Holl land

0ak Ridge National Laboratory

P. O. Box $X$

Oak Ridge, TN 37830

H. Hollister, Assistant Secretary

Environmental Protection, Safety

and Emergency Preparedness

EP-1, FORSTL

U.S. Department of Energy

Washington, DC 20585

G. R. Holt

ARCO Coal Company

3860 North Lincoln St.

P. 0. Box 5300

Denver, C0 80217

P. House

EP-33, FORSTL

U.S. Department of Energy

Washington, DC 20585

W. Hubis

Gulf Mineral Resources

1720 South 8ellaire

Denver, CO 80222

S. Ikeda

Japan Coal Liquefaction

Development Co., Ltd.

Rm 1115, Shuwa Kioi-Cho TBR Bldg.

No. 7, Kojimachi 5-chome,

Chiyoda-Ku, Tokyo 102

JAPAN

H. Inhaber

Oak Ridge National Laboratory

P. 0. Box $X$

Oak Ridge, TN 37830

K. Janes (2)

Environmental Protection Agency

401 M Street, SW

Washington, DC 20460

J. C. Johnson

FE-13, GTN

U.S. Department of Energy

Washington, DC 20545

W. S. Jones

FE-43, GTN

U.S. Department of Energy

Washington, DC 20545 
L. Joseph

Hydrocarbon Research, Inc.

1313 Dolly Madison Blvd.

McLean, VA 22101

J. S. Kane, Deputy Director

Office of Energy Research

ER-2, FORSTL

U.S. Department of Energy

Washington, DC 20585

C. M. Kelly

International Coal Refining Co.

P. 0. Box 2752

Allentown, PA 18001

D. L. Kloepper

The Pittsburg \& Midway

Coal Mining Company

P. 0. Box 3396

Denver, C0 80155

S. C. Lewis

Exxon Corporation

Research and Environmental Health Division

Medica1 Department

P. 0 . Box 235

East Millstone, NJ 08873

J. M. Lockard

University of Kentucky

College of Arts and Sciences

Lexington, KY 40506

M. J. Massey (2)

Environmental Research and

Technology, Inc.

601 Grant Street

Porter Building, 10th Floor

Pittsburgh, PA 15219

H. McCammon

ER-75, GTN

U.S. Department of Energy

Washington, DC 20545

R. 0. McClellan

Lovelace Inhalation Toxicology

Research Institute

P. 0. Box 5890

Albuquerque, NM 87115
G. V. McGurl

Pittsburgh Energy Technology Center

P. 0. Box 10940

Pittsburgh, PA 15236

R. E. McKee

Exxon Corp.

Research and Environmental

Health Division

Medical Department

P. 0. Box 235

East Millstone, NJ 08873

P. M. Mehrle

Columbia National Fisheries Re-

search Laboratory

Route 1

Columbia, M0 65201

M. L. Mendelsohn

Lawrence Livermore Laboratory

University of California

P. 0. Box 808

Livermore, CA 94550

L. Miller (2)

FE-42, GTN

U.S. Department of Energy

Washington, DC 20545

M. L. Minthorn

ER-72, GTN

U.S. Department of Energy

Washington, DC 20545

A. Moghissi

U.S. Environmental Protection Agency

401 M Street, SW

Washington, DC 20460

Morgantown Public Library (2)

373 Spruce Street

Morgantown, WV 26505

E. C. Moroni

FE-43, GIN

U.S. Department of Energy

Washington, DC 20545

J. L. Morris

FE-44, GTN

U.S. Department of Energy

Washington, DC 20545 


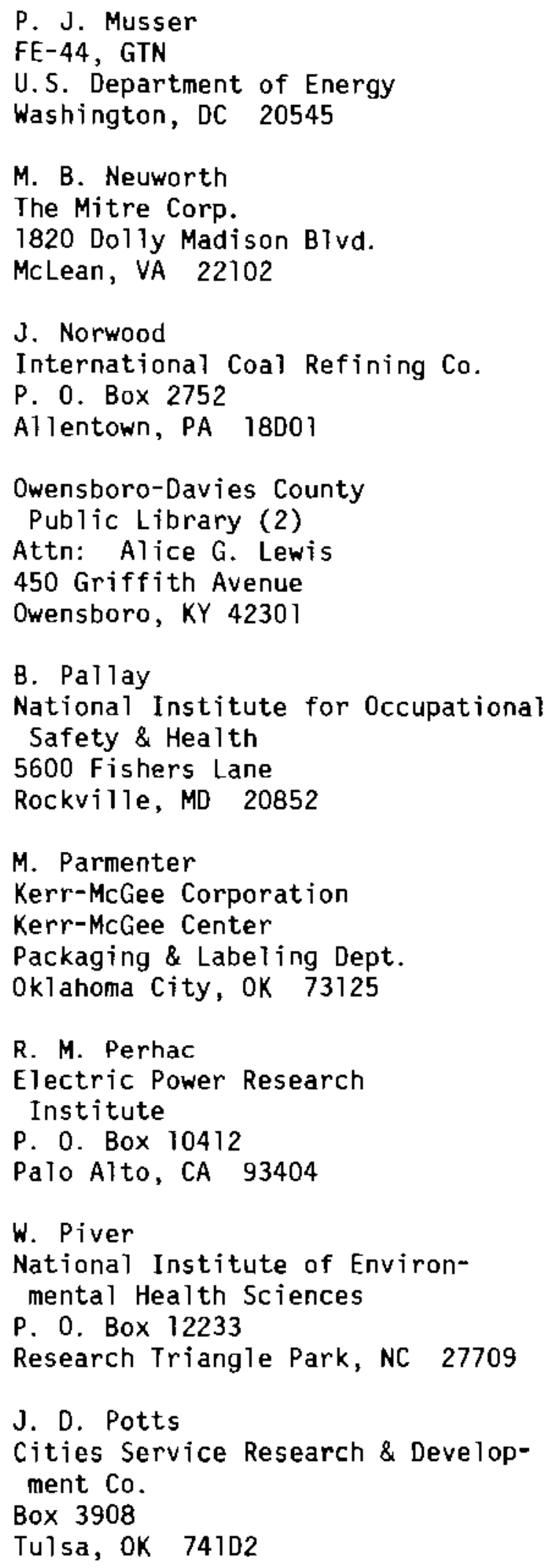

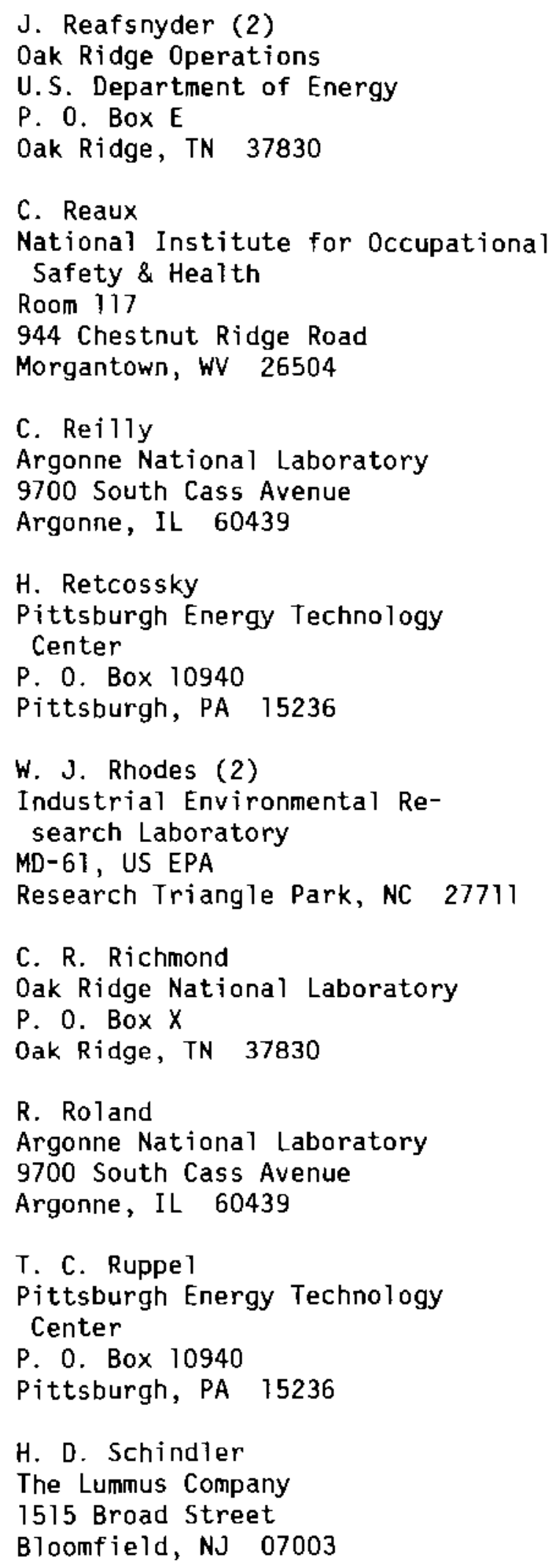


D. K. Schmalzer

The Pittsburg \& Midway

Coal Mining Co.

P. 0. Box 3396

Denver, Co 80155

E. Schmetz

FE-43, GTN

U.S. Department of Energy

Washington, DC 20545

M. Schulman

ER-70, GTN

U.S. Department of Energy

Washington, DC 20545

0. J. Schwarz

Botany Department

University of Tennessee

Knoxville, TN 37916

R. Scripsick

P. 0. Box 1663, MS-986

tos Alamos, NM 87545

A. G. Sharkey

Pittsburgh Energy Technology Center

P. 0. Box 10940

Pittsburgh, PA 15236

A. Shepard

American Petroleum Institute

2101 L Street, NW

Washington, DC 20037

C. Shih

TRWI Space Park

R42142

Redondo Beach, CA 90278

D. A. Smith

ER-72, GTN

U.S. Department of Energy

Washington, DC 20545

G. E. Stapleton

ER-72, GTN

U.S. Department of Energy

Washington, DC 20545

J. Stasior

Enviro Control

11300 Rockville Pike

Rockvilie, MD 20852
R. J. Stern

EP-33, FORSTL

U.S. Department of Energy

Washington, DC 20585

J. Stetter

Argonne National Laboratory

9700 South Cass Avenue

Argonne, IL 60439

J. A. Strasser

Atlantic Coal Institute

P. 0. Box 1133

Sydney, Nova Scotia

CANADA BIP 6.57

J. Taity

National Institute for Occupational

Safety \& Health

5600 Fishers Lane

Rockville, MD 20852

J. Tao

International Coal Refining Co.

P. 0. Box 2752

Allentown, PA 1800 ?

J. W. Thiessen

Deputy Associate Director

office of Health and Environ-

mental Research

ER-71, GTN

U.S. Department of Energy

Washington, DC 20545

G. G. Thurlow

National Coal Board

Coal Research Establishment

Stoke Orchard

Cheltenham, Glos. GL52 4RZ

ENGLAND

R. V. Trense

Exxon Corporation

Environmental Affairs Programs

Exxon Research \& Engineering Co.

P. D. Box 101

Florham Park, NJ 07932

A. W. Trivelpiece, Director (3)

Office of Energy Research

ER- I, FORSTL

U.S. Department of Energy

Washington, DC 20585 
University of Kentucky (2)

Attn: J. Pivarnik

Government Publications

Department

M. L. King Library

Lexington, KY 40506

G. K. Vick (2)

Exxon Corporation

P. 0. Box 101

Fiorham Park, NJ 07932

G. L. Voelz

University of California

Los Alamos Scientific Laboratory

P. 0. Box 1663

Los Alamos, NM 97545

Library (2)

West Virginia University

Downtown Campus

Attn: C. Hamerick

Morgantown, WV 26505

K. Wilzbach (4)

Argonne National Laboratory

9800 South Cass Avenue

Argonne, IL 60439

F. E. Witmer

EP-33, GTN

U.S. Department of Energy

Washington, DC 20545

F. J. Wobber (10)

ER-75, GTN

U.S. Department of Energy

Washington, DC 20545

R. W. Wood

ER-74, GTN

U.S. Department of Energy

Washington, DC 20545

ONSITE

DOE Richland Dperations Office

(2)

H. E. Ransom

P. K. Clark
Pacific Northwest Laboratory (128)

L. E. Anderson

W. J. Bair

R. M. Bean

C. D. Becker

F. G. Burton

W. C. Cannon

D. A. Cataldo

J. F. Cline

D. D. Oauble

H. Drucker (30)

W. E. Falion

L. J. Felice

W. D. Felix

D. H. Fickeisen

M. E. Frazier

R. H. Gray (30)

P. L. Hackett

G. A. Halseth

D. R. Kalkwarf

M. T. Karagianes

B. J. Kelman

J. C. Kutt

S. M. Loscutoff

R. H. Lovely

D. D. Mahlum

S. Marks

R. P. Marshall

P. J. Mellinger

L. 0. Montgomery

J. E. Morris

D. R. Moss

T. Nelson

J. M. Nielsen

D. E. 0lesen

T. L. Page

R. A. Pelroy

R. W. Perkins

M. R. Petersen

R. D. Phillips

T. M. Poston

H. A. Ragan

R. A. Renne

R. E. Schirmer

R. P. Schneider

D. M. Schoengold

M. R. Sikov

S. D. Sklarew

L. G. Smith

D. L. Springer

J. A. Strand 

W. L. Templeton
T. A. Toste
D. Tolley
B. E. Vaughan
B. A. Vieux
M. L. Warner
W. C. Weimer
R. E. Wildung

W. R. Wiley

D. H. Willard

C. Willey

B. W. Wilson

Biology Publications Office

Technical Information (5)

Publishing Coordination (2) 
